\title{
REVIEW
}

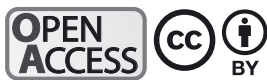

\section{Informing research priorities for immature sea turtles through expert elicitation}

\author{
Natalie E. Wildermann ${ }^{1}$, Christian Gredzens ${ }^{1}$, Larisa Avens, Héctor A. \\ Barrios-Garrido ${ }^{1}$, Ian Bell, Janice Blumenthal, Alan B. Bolten, Joanne Braun McNeill, \\ Paolo Casale, Maikon Di Domenico, Camila Domit, Sheryan P. Epperly, Matthew H. \\ Godfrey, Brendan J. Godley, Victoria González-Carman, Mark Hamann, Kristen M. \\ Hart, Takashi Ishihara, Kate L. Mansfield, Tasha L. Metz, Jeffrey D. Miller, Nicolas J. \\ Pilcher, Mark A. Read, Christopher Sasso, Jeffrey A. Seminoff, Erin E. Seney, \\ Amanda Southwood Williard, Jesús Tomás, Gabriela M. Vélez-Rubio, Matthew \\ Ware $^{1}$, Jessica L. Williams, Jeanette Wyneken, Mariana M. P. B. Fuentes ${ }^{1, *}$
}

${ }^{1}$ Marine Turtle Research, Ecology and Conservation Group, Department of Earth, Ocean and Atmospheric Science, Florida State University, Tallahassee, FL 32306, USA

Addresses for other authors are given in the Supplement at www.int-res.com/articles/suppl/n037p055_supp.pdf

\begin{abstract}
Although sea turtles have received substantial focus worldwide, research on the immature life stages is still relatively limited. The latter is of particular importance, given that a large proportion of sea turtle populations comprises immature individuals. We set out to identify knowledge gaps and identify the main barriers hindering research in this field. We analyzed the perceptions of sea turtle experts through an online survey which gathered their opinions on the current state of affairs on immature sea turtle research, including species and regions in need of further study, priority research questions, and barriers that have interfered with the advancement of research. Our gap analysis indicates that studies on immature leatherback Dermochelys coriacea and hawksbill Eretmochelys imbricata turtles are lacking, as are studies on all species based in the Indian, South Pacific, and South Atlantic Oceans. Experts also perceived that studies in population ecology, namely on survivorship and demography, and habitat use/behavior, are needed to advance the state of knowledge on immature sea turtles. Our survey findings indicate the need for more interdisciplinary research, collaborative efforts (e.g. data-sharing, joint field activities), and improved communication among researchers, funding bodies, stakeholders, and decision-makers.
\end{abstract}

KEY WORDS: Marine turtle $\cdot$ Juvenile turtle $\cdot$ Subadult turtle $\cdot$ Research priority $\cdot$ Management priority $\cdot$ Cheloniidae $\cdot$ Dermochelyidae

\section{INTRODUCTION}

Over the past 3 decades, research interest in sea turtle biology and conservation has increased (Hamann et al. 2010, Rees et al. 2016). The concomitant and staggering expansion in the range of research conducted is likely linked to the fact that multiple

${ }^{*}$ Corresponding author: mfuentes@fsu.edu populations of sea turtles are of significant conservation concern (Wallace et al. 2011). Protection status and population trends are highly variable among sea turtle management units. Some populations display consistent increases in numbers after long-term conservation efforts (e.g. green turtles Chelonia mydas in Hawaii and the Atlantic and Indian Oceans,

() The authors 2018. Open Access under Creative Commons by Attribution Licence. Use, distribution and reproduction are unrestricted. Authors and original publication must be credited. 
hawksbill turtles Eretmochelys imbricata in the Western Atlantic Ocean, and loggerhead turtles Caretta caretta in the Mediterranean; Pilcher et al. 2012, Weber et al. 2014, Casale 2015, Mazaris et al. 2017), and others remain vulnerable to persistent threats and are considered Critically Endangered (e.g. Pacific leatherback turtles Dermochelys coriacea; Tiwari et al. 2013, Wallace et al. 2013b). To date, studies have focused on a multitude of topics ranging from addressing ecological questions such as diet preferences, trophic niche, age and growth rates, genetic stocks, and reproduction (Lutz \& Musick 1997, Lutz et al. 2003, see Wyneken et al. 2013), to more applied questions investigating fisheries interactions and bycatch rates, management strategies, and threat assessments (Maxwell et al. 2013, Mazor et al. 2013, Gredzens et al. 2014, Senko et al. 2014, Fuentes et al. 2015).

Despite a mean annual increase of $9 \%$ in sea turtle peer-reviewed publications since 1980 (Fig. 1), knowledge gaps still exist for individual species and life stages. It is important to identify these gaps to inform future research priorities and effective conservation actions for those species in need, particularly focusing on regional subpopulations and management units (Wallace et al. 2010b). Several efforts have focused on identifying these gaps and future priorities, but most of the recommendations either have a broad-scale focus on all life stages, or are specific to research techniques (e.g. satellite tracking; Godley et al. 2008, Hart \& Hyrenbach 2009, Hazen et al. 2012,
Shillinger et al. 2012, Jeffers \& Godley 2016), or threats (e.g. fisheries, climate change, plastic pollution; Lewison et al. 2004, Hawkes et al. 2009, Wallace et al. 2010a, Casale et al. 2016, Nelms et al. 2016a). However, common to all these efforts is the recommendation for increased studies on immature life stages (Crouse et al. 1987, Hamann et al. 2010, Bjorndal et al. 2011, Rees et al. 2016). In this paper, we broadly define immature sea turtles as individuals that have recently transitioned to developmental and/or foraging habitats until they reach sexual maturity; we considered developmental and foraging habitats in both neritic and oceanic environments. Given that there is no clear temporal or geographical boundary to delimit when and where a hatchling transitions to developmental and/or foraging habitats, we excluded from our study research on hatchlings during their terrestrial phase, as well as in situ and ex situ research on hatchlings and post-hatchlings during the first few weeks of life.

Sea turtles spend almost all of their life in the water. However, limited accessibility to in-water individuals tends to hinder research, even more so in offshore oceanic environments than near-shore coastal habitats (Hamann et al. 2010, Mansfield et al. 2012). Several long-term studies in foraging areas have provided comprehensive knowledge on the general foraging ecology of sea turtles (e.g. in Hawaii, Balazs 1980; eastern Australia, Limpus 1992; Bahamas, Bjorndal et al. 2000; Bermuda, Meylan et al. 2011; Puerto Rico, van Dam \& Diez 1999). Never-

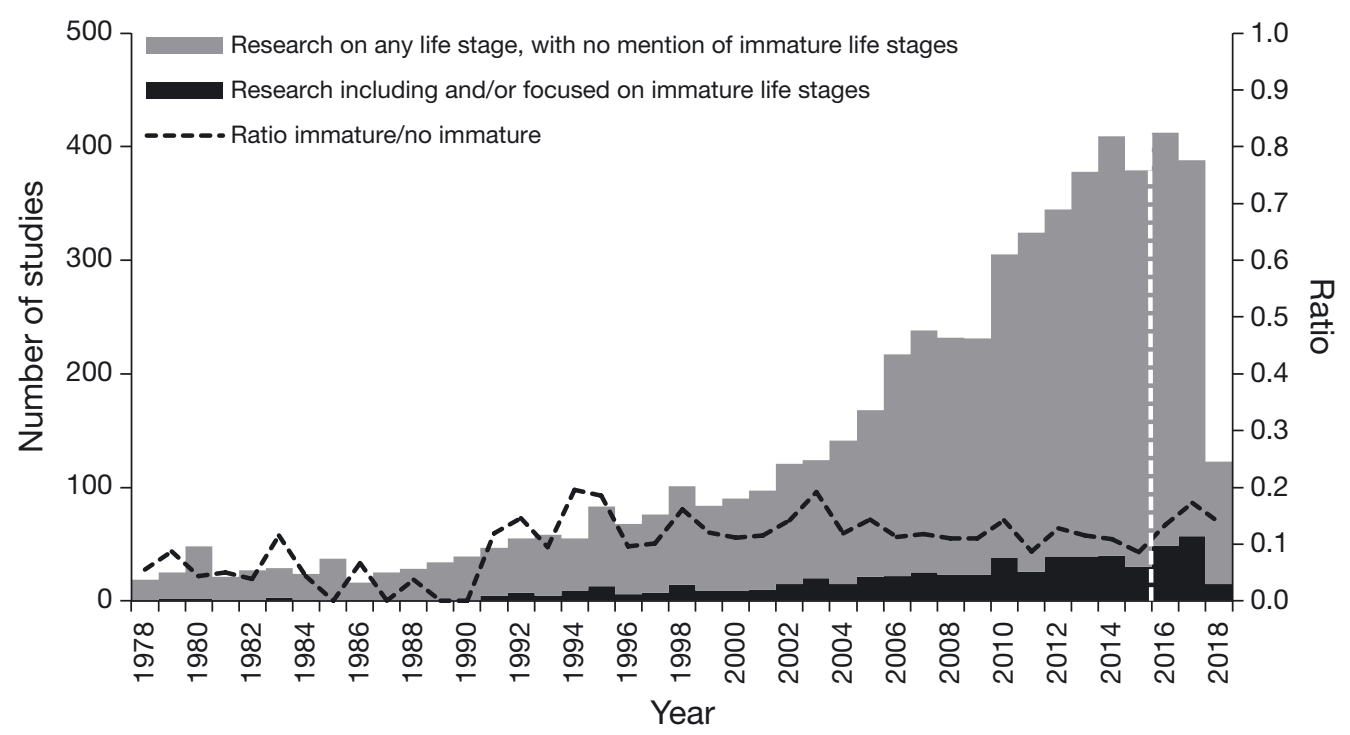

Fig. 1. Count (number of studies) and ratio of sea turtle research publications from 1978 to April 2018 from a Web of Science search using the search terms 'sea turtle' or 'marine turtle' for any life stage (gray bars) and for studies including or focused on immature turtles (black bars). White dashed line indicates end of sampling for literature review to identify experts. Prior to 1978, there were limited and temporally scattered studies on immature sea turtles; thus these studies were excluded from the search. From 1978 onwards, annual frequency of peer-reviewed studies on immature sea turtles started to increase 
theless, there are still substantial knowledge gaps in the in-water ecology of sea turtles, particularly for pre-reproductive life stages. This represents a major limitation for species like sea turtles, for which immature individuals are the most abundant life stages in the population (Crouse et al. 1987, Heppel et al. 1996, Casale \& Heppell 2016).

Synthesizing the current level of knowledge of immature sea turtles, their habitats, and the conservation challenges impacting this life stage is crucial for prioritizing future research needs and informing appropriate design of management and conservation actions. This study addresses research needs of immature sea turtles within developmental habitats (both neritic and oceanic, dependent on species). Our objectives were to identify existing knowledge gaps and research priorities for the immature life stages, as well as the barriers that hinder the advancement of research in this field. To address these objectives, we used targeted surveys to integrate the knowledge and expertise of current sea turtle researchers, resource managers, and conservationists across the globe who are studying, managing, and conserving immature life stages of sea turtles.

\section{METHODS}

\section{Sampling and survey design}

To identify existing knowledge gaps and research priorities for immature turtles, we elicited information from experts through the online tool SurveyMonkey (www.surveymonkey.com) between 21 September and 1 November 2015. Experts were identified through a combination of researcher profiles on the International Union for the Conservation of Nature Marine Turtle Specialist Group (IUCN-MTSG) website (http://iucn-mtsg.org/) indicating research on immature sea turtles and a literature review on the Web of Science ${ }^{\mathrm{TM}}$ (www.webofknowledge.com). For the literature review, we queried peer-reviewed articles published by November 2015, which included the terms 'immature,' 'juvenile' OR 'sub-adult,' AND 'sea turtle' OR 'marine turtle' in the topic or title fields. Each returned article was then manually screened for relevancy to immature life stages of sea turtles.

Identified experts were contacted via email with a statement explaining the nature of the research and a link to the online survey. The survey also included a question asking participants to suggest up to 5 experts that work in the field (i.e. snowball method;
Biernacki \& Waldorf 1981). This snowballing approach provided us with a representative sample as respondents began to provide similar additional experts to the ones we had already identified. Respondents were later invited to be co-authors.

A voluntary survey composed of 11 questions grouped in 2 sections was used to elicit responses from the identified experts (Table 1). The first section contained 4 questions (Q1-Q4), which focused on identifying each participant's area of expertise and experience. The second section contained 7 questions, which focused on participants' opinions on the current global state of knowledge (Q5), research priorities (Q6-Q9), critical research questions (Q10), and barriers that impede addressing these questions (Q11).

\section{Data analysis}

Ranked questions were analyzed using the Probability Models for Ranking Data 'pmr package' (Lee \& Yu 2013) in R (R Core Team 2016) to determine the mean rank, based on the number of times each category was ranked in each priority level. The number of times each item was ranked in the top 3 choices was then analyzed to determine the most important areas that were perceived as research priorities. Cross tabulations were also performed to determine correlations between respondent selections and respondent experience (e.g. were researchers more likely to choose species or locations in which they worked?).

Responses to the last 2 questions on the survey (regarding critical research questions and barriers to research) were first open-coded (based on common wording and ideas) and grouped into common themes. If a response fell under 2 or more common themes, then the most dominant theme was assigned (Auerbach \& Silverstein 2003, Hamann et al. 2010). Critical questions were separated into 4 themes: (1) population ecology: including questions on age and growth, population structure, and size; (2) habitat use/behavior: including distribution, movement, and habitat; (3) threats; and (4) management. Barriers were separated into 6 common themes: (1) data paucity: herein defined as lack of baseline/long-term data; (2) funding issues: high research cost and limited resources, especially for longer-term research; (3) accessibility constraints: logistical difficulties related to encountering and capturing individuals; (4) limited sharing/collaboration: lack of coordination between researches, stakeholders, and managers; 
(5) limited support capacity: lack of existing capacity/ skills to undertake research and lack of external interest for supporting research (e.g. from the community, donors, political interest, permitting); and (6) technological issues: limitations in the extent to which existing methods can be used to expand research. Once all responses were compiled into themes, survey participants who indicated that they were willing to provide further input on their responses $(\mathrm{N}=15)$ were contacted to rank the top 5 critical questions and barriers within each theme (e.g. Sutherland et al. 2008, Hamann et al. 2010, Lewison et al. 2012). We calcu-

Table 1. Survey questions regarding the state of knowledge on immature sea turtles given to participants with options provided for response in brackets, and the number of responses for each question

Question

No. of responses

Section 1 - Area of expertise

Q1. Are you a researcher or natural resource manager? (Researcher, Manager, Both)

30

How long have you been working in your respective field? $(<5 \mathrm{yr}, 6-10 \mathrm{yr}, 11-20 \mathrm{yr},>21 \mathrm{yr})$

Please indicate the proportion of your work experience spent in the following types of organizations (Government management agency, Government research agency, Academia/ University, NGOs, Private business/Industry, Other: please specify)

Q4. Which juvenile marine turtle Regional Management Units (RMUs) have you worked with or currently work with? (Loggerhead turtles: Northwest Atlantic, Northeast Atlantic, Southwest Atlantic, Mediterranean, Southwest Indian, Northwest Indian, South Pacific, North Pacific, $i$ Green turtles: Central Atlantic, South Caribbean, Northwest Atlantic, Southwest Atlantic, Mediterranean, Northwest Indian, Southeast Indian, Southwest Indian, East Pacific, West Pacific, Northwest Pacific, North Central Pacific, South Central Pacific, West Central Pacific, Southwest Pacific; Leatherback turtles: Northwest Atlantic, Southwest Atlantic, Southeast Atlantic, East Pacific, West Pacific; Hawksbill turtles: East Atlantic, Southwest Atlantic, West Atlantic, Northwest Indian, Southwest Indian, Southeast Indian, North Central Pacific, South Central Pacific, East Pacific, Southwest Pacific, West Pacific; Olive ridley turtles: West Atlantic, East Atlantic, Northeast Indian, West Pacific, East Pacific; Kemp's ridley turtles: Northwest Atlantic; Flatback turtles: Southeast Indian, Southwest Indian, Southwest Pacific)

Section 2 - Research priorities

Q5. In your opinion, what is the current global state of knowledge that allows us to understand and plan for conserving and managing juvenile marine turtles and their developmental habitat? (Infancy, Developing, Developed, Advanced)

Q6. Thinking about the global state of knowledge about juvenile marine turtles and their developmental habitat, which regions of the world do you think need the most research attention to enable better management and conservation (choose up to 3)? (North Atlantic, South Atlantic, North Pacific, South Pacific, Gulf of Mexico, Caribbean, Central America, Mediterranean, Australia, Indian Ocean, Other: please specify)

Q7. Thinking about the global state of knowledge about juvenile marine turtles and their developmental habitat, which regions of the world do you think need the least research attention to enable better management and conservation (choose up to 3)? (North Atlantic, South Atlantic, North Pacific, South Pacific, Gulf of Mexico, Caribbean, Central America, Mediterranean, Australia, Indian Ocean, Other: please specify)

Q8. Thinking about the global state of knowledge about juvenile marine turtles and their developmental habitat, which species do you think need the most research attention to enable better management and conservation (Ranked scale from 1 to 7 , with 1 being highest priority)? (Loggerhead Caretta caretta, green Chelonia mydas, hawksbill Eretmochelys imbricata, Kemp's ridley Lepidochelys kempii, olive ridley Lepidochelys olivacea, leatherback Dermochelys coriacea, flatback Natator depressus)

Q9. Thinking about the global state of knowledge about juvenile marine turtles and their developmental habitat, which research topics do you think need the most research attention to enable better management and conservation (Ranked scale from 1 to 11, with 1 being highest priority)? (Movement, Distribution, Habitat, Population ecology, Health/Rehabilitation, Growth, Diet, Morphology, Age, Threats, Other: please specify)

Q10. What are the critical research questions that need to be answered to support conservation and management of the species you think require the most attention? (Open-ended)

Q11. Can you list the main barriers that get in the way of these research questions being addressed? (Open-ended) 
lated the percentage of prevalence of the responses to define the most important areas/themes, followed by the mean rank of each individual question/barrier to identify the top 5 choices for each area/theme.

We applied a multiple correspondence analysis (MCA) (Husson et al. 2010) using the Burt table method (Burt 1950) to assess the response patterns of the survey participants. MCA is an extension of correspondence analysis (CA) and elucidates the relationship patterns among several categorical dependent variables (Burt 1950). We included the following variables in our qualitative data matrix: years of experience, role, region where they have worked (based on regional management units [RMUs] selected by respondents), species they have experience with (based on RMUs selected by respondents), region and species considered as highest priority for future research, research topic with highest priority, and most important barriers hindering research. The questions for 'role' and 'years of experience' were coded as supplementary variables; all other questions were coded as qualitative variables. Supplementary variables were not included in the structure and classification of the participants' responses, and were used to visually assess further patterns in the MCA plots. All analyses and graphics were computed with the packages FactoMineR (Lê et al. 2008) and factoextra (Kassambara \& Mundt 2017) in R.

\section{RESULTS}

\section{Respondents}

The literature review returned 485 peer-reviewed articles relevant to immature sea turtle research between the years 1913 and 2015. Thirty-four experts were identified for the initial round of surveys, through the IUCN MTSG website and the authorship of recent articles (from 2000 to 2015) queried in the Web of Science. The snowballing effect provided another 34 experts, for a total of 68 experts who were then contacted to participate in the survey. A total of 30 respondents completed the survey $(\sim 47 \%$ response rate). Of these respondents, the majority (60\%) had more than 20 yr of experience working with immature sea turtles, 30\% had between 11 and $20 \mathrm{yr}$ of experience, while the remaining $10 \%$ had 6 to $10 \mathrm{yr}$ of experience (Fig. 2a). Most respondents identified themselves as researchers (80\%), while the remainder identified themselves as both a researcher and a resource manager (Fig. 2b). There were no trends in the responses based on the role of the respondents.
Respondents had experience working with all species of sea turtles, with the majority having experience with green turtles (93\%), loggerheads (90\%), and hawksbill turtles (70\%) (Fig. 2c). There was also a near global coverage of RMUs (Wallace et al. 2010b), with only 7 RMUs out of 58 (12\%) not being represented by any of the respondents; of these RMUs, 6 were located within the Indian Ocean and 1
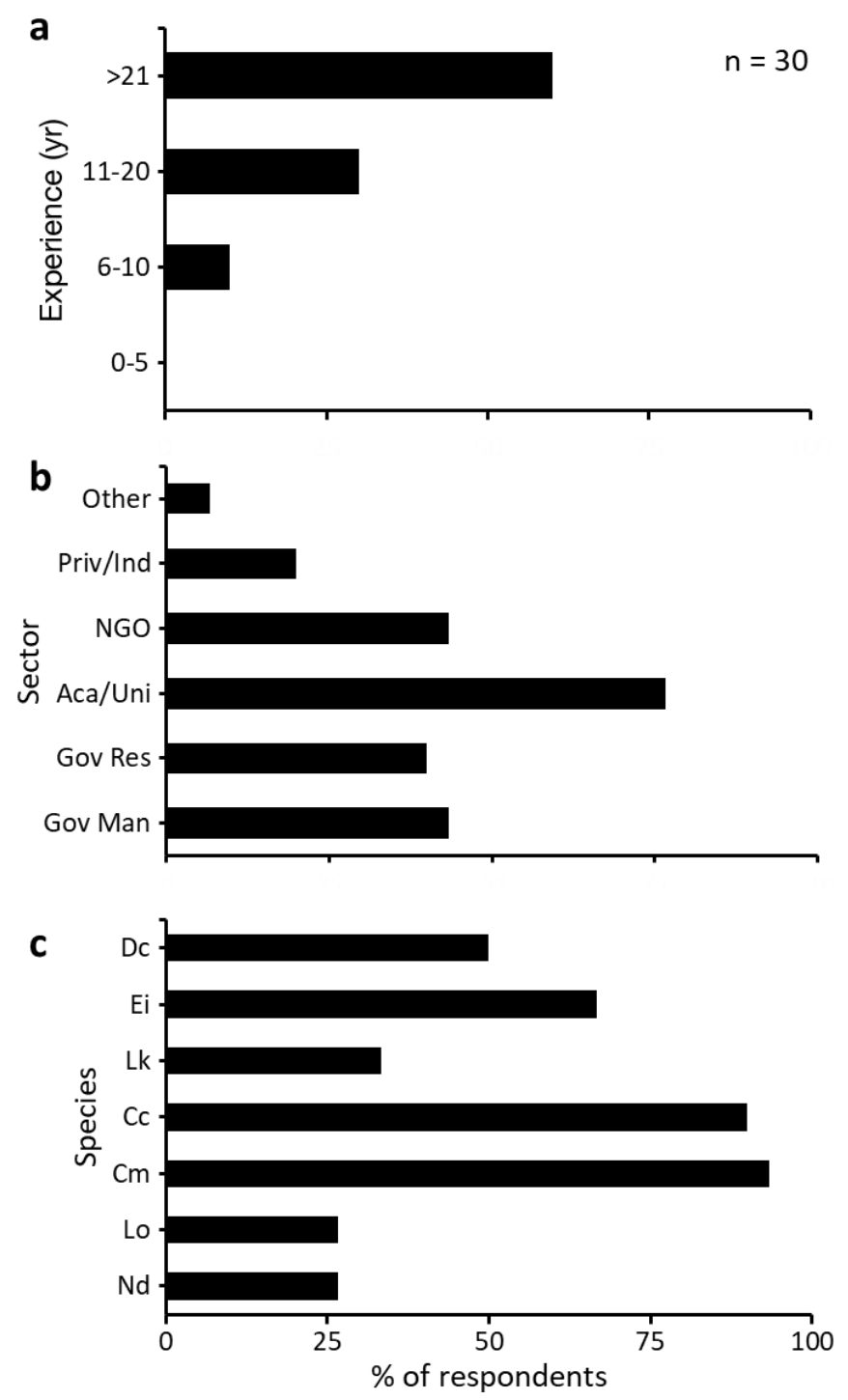

Fig. 2. Summary of survey respondents' (a) expertise, (b) employment sector, and (c) species researched. Priv/Ind: private sector or industry, NGO: non-governmental organization, Aca/Uni: academia or university, Gov Res: government research, Gov Man: government management, Dc: leatherback turtle Dermochelys coriacea, Ei: hawksbill turtle Eretmochelys imbricata, Lk: Kemp's ridley turtle Lepidochelys kempii, Cc: loggerhead turtle Caretta caretta, Cm: green turtle Chelonia mydas, Lo: olive riddle turtle Lepidochelys olivacea, $\mathrm{Nd}$ : flatback turtle Natator depressus. Respondents could pick more than 1 category for (b) and (c) 
in the west-central Pacific Ocean. In terms of regions, the majority of respondents (51\%) had experience with RMUs in the Atlantic, 30\% in the Pacific, 13\% in the Indian, and $6 \%$ in the Mediterranean regions. Clusters of responses based on the region where respondents have worked were evident for researchers from the Mediterranean and Atlantic regions (left quadrants in Fig. 3a), and Indian and Pacific regions (right quadrants in Fig. 3a) (also see Table S1 in the Supplement at www.int-res.com/articles/suppl/n037 p055_supp.pdf).

\section{Current global state of knowledge}

The majority of respondents (80\%) indicated they perceived the current global knowledge of immature turtles to be still developing. None of the respondents considered the field to be in advanced stages. When looking at cumulative years of experience, all respondents in their early career ( 6 to $10 \mathrm{yr}$ ) perceived the field to be developing, while as years of experience increased, so did the relative proportion of respondents who perceived the field to be more developed (11\% for 11-20 yr, $22 \%$ for greater than $20 \mathrm{yr}$ ).

\section{Priorities to address research needs}

Species. Most respondents (80\%) identified immature leatherbacks as being in critical need of more research by ranking them within their top 3 choices for priority species (Fig. 4a). Hawksbill turtles were identified as the second species with priority research needs, with $63 \%$ ranking this species in their top 3 choices and one-third had it as their second choice (Fig. 4a) for priority research needs. The remaining species were ranked similarly in terms of their top 3 choices for priority research needs (Fig. 4a). Based on the papers in our literature review (Table S2a), the vast majority of existing studies until 2015 focused on loggerhead (35\%) and green turtles (35\%), followed by studies on hawksbill (13\%) and Kemp's ridley turtles $(10 \%)$. Just a few studies focused on leatherback $(5 \%)$, olive ridley $(2 \%)$, and flatback turtles $(0.3 \%)$. There was no relationship among the responses regarding species with which respondents had experience (Fig. 3b, Tables S1 \& S2). However, species considered as priority by respondents were strongly related to the priority research topics, indicating that research needs will vary depending on the species of focus (Fig. 3c,d; Table S1). When asked to identify species that require more research, only $14 \%$ of re- spondents selected species with which they had experience (Table S3).

Regions. The Indian Ocean (excluding Australia) was identified as the area requiring the most attention for future research on immature turtles and their developmental habitats (Fig. 5). For the Indian Ocean, $86 \%$ of respondents who had experience in the region ( 6 out of 7 ) selected it as a priority area for research (Table S4). Moreover, respondents working in other regions selected the Indian Ocean as a priority area $66 \%$ of the times $(\mathrm{N}=74)$, and no respondent selected it as an area of lower priority for research, indicating its importance as a priority area. The next 2 most frequently listed priority areas were the South Pacific (excluding Australia) and South Atlantic, with 39 and $36 \%$ of responses, respectively (Fig. 5). In most cases, respondents (from 7 out of 9 regions) did not consider the region in which they worked as the highest priority (Table S4). The exceptions were those who worked in the Gulf of Mexico and Indian Ocean (excluding Australia).

For the regions of lower research priority for immature turtles and their developmental habitat, the North Atlantic Ocean (excluding the Caribbean, Gulf of Mexico, and Central America) was selected by $74 \%$ of respondents (Fig. 5). Additionally, two-thirds of respondents with experience in the region (10 out of 15) indicated that the North Atlantic was an area of lower priority for research (Table S5). Other regions selected as lower priority for research were Australia (37\% selection rate), the Caribbean (excluding the Gulf of Mexico and Central America; 30\%), and the Mediterranean (30\%) (Fig. 5).

\section{Research topics}

Studies on population ecology were ranked first, with almost $50 \%$ of respondents selecting this research topic as their number one choice (Fig. 4b). Areas related to habitat ecology were ranked next in priority, namely distribution and habitat use/behavior. Further research topics considered priority by respondents were threats, movement, age, and growth. Diet, health, or morphology were not considered as high priority research topics. Population ecology/ abundance and distribution were priorities chosen by respondents from all regions, as evidenced by the wide spread of responses across the MCA plot (Fig. 3a,d). However, research on threats and habitats were considered priority areas by respondents from the Atlantic, Mediterranean, and Indian Ocean regions (Fig. 3a,d). 

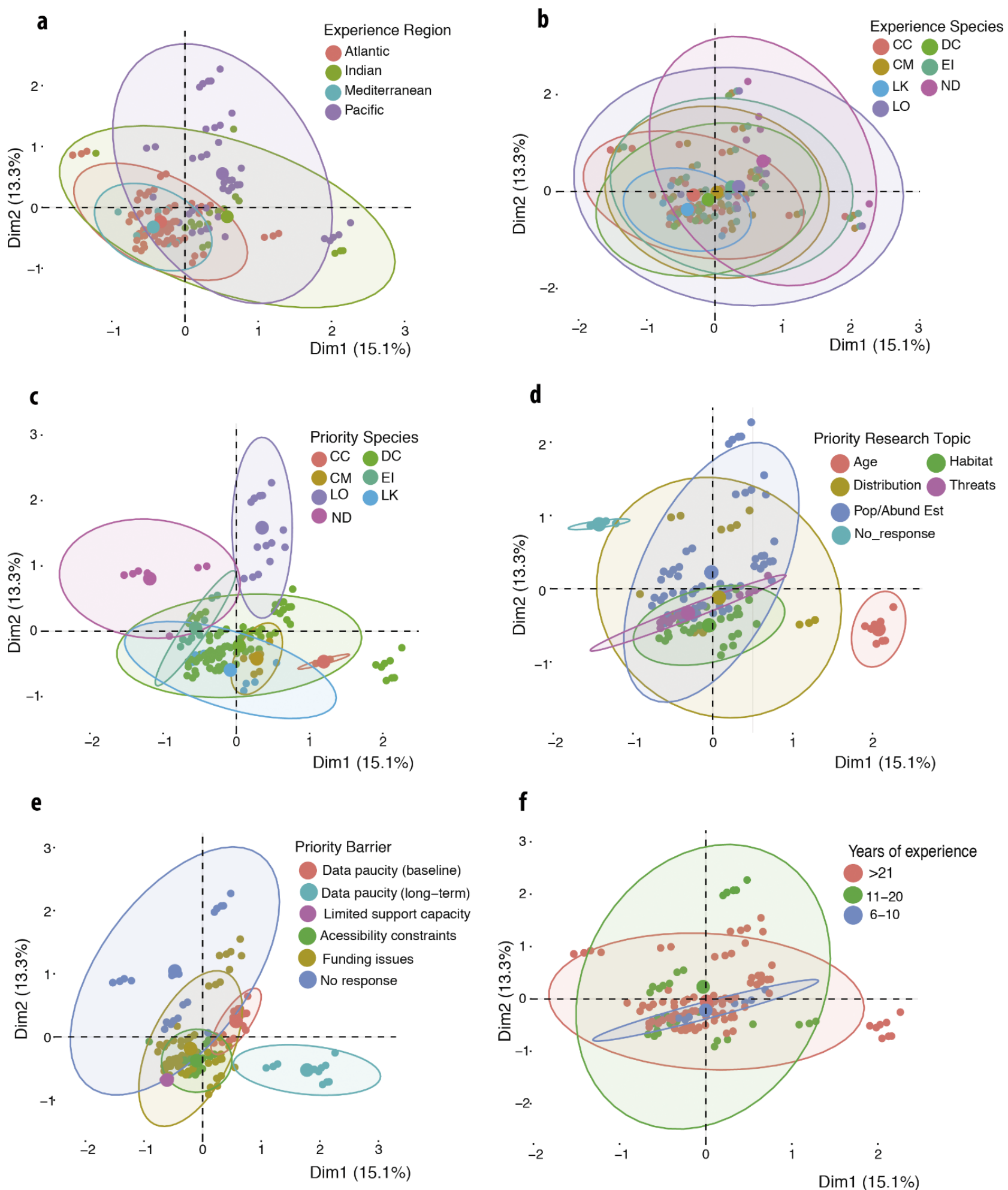

Fig. 3. Multiple correspondence analysis (MCA) plots for qualitative variables. Points represent answers from respondents and clusters are generated for answers of the same category based on: (a) region where respondents have worked ('Experience region'), (b) species respondents have worked with ('Experience species'), (c) priority species for research ('Priority species'), (d) research topic with highest priority ('Priority research topic'), (e) most important barrier hindering research ('Priority barrier'), and (f) years of experience. The dimensions (Dim1 and Dim2) represent all surveyed variables, and the variables strongest correlated $\left(\mathrm{R}^{2}\right)$ with each dimension are shown in Table S1 in the Supplement at www.int-res.com/articles/suppl/n037p055_supp.pdf. 
a

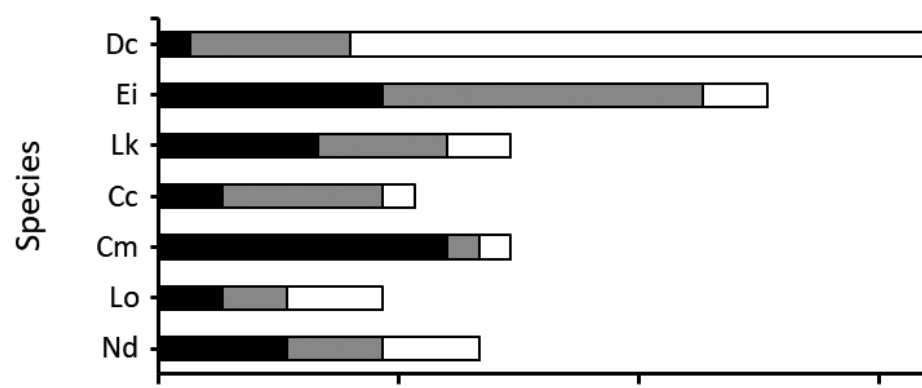

Mean rank

2.10

3.17

4.17

4.47

4.57

4.70

4.83

Mean rank

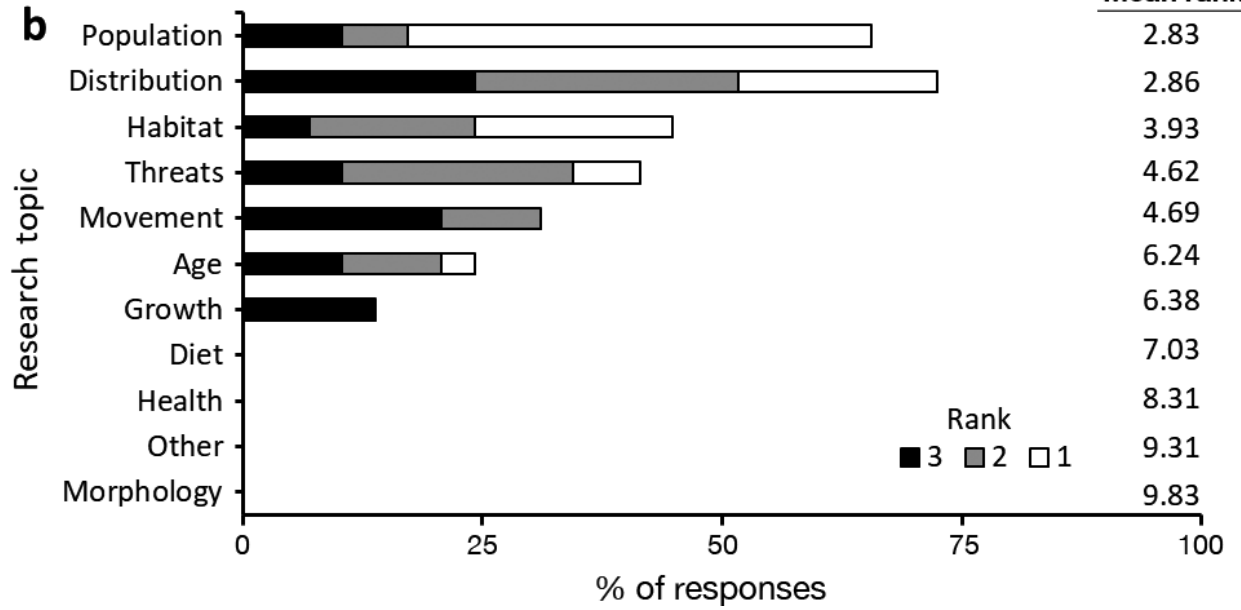

Fig. 4. Ranked immature sea turtle (a) priority species and (b) research topics as determined by expert opinion. Ranks ranged from 1 to 11 , with lower ranks indicating the higher priority. Species abbreviations as in Fig. 2

\section{Critical research questions}

Respondents provided a total of 101 unique critical research questions. Open-coding of responses for common themes resulted in 4 priority themes: (1)

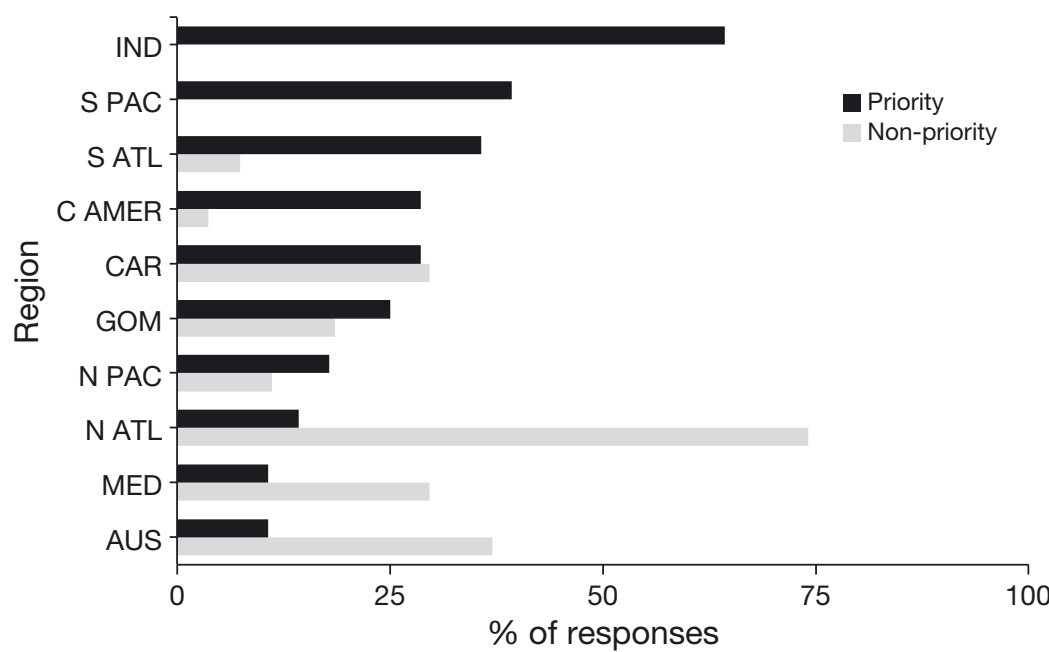

Fig. 5. Perceived priority and non-priority regions for immature sea turtle research, conservation, and management. IND: Indian Ocean, S PAC: South Pacific, S ATL: South Atlantic, C AMER: Central America, CAR: Caribbean, GOM: Gulf of Mexico, N PAC: North Pacific, N ATL: North Atlantic, MED: Mediterranean, AUS: Australia. Respondents could provide up to 3 regions for both priority and non-priority areas population ecology ( $37 \%$ of critical research questions), (2) habitat use and behavior (27\%), (3) threat identification (19\%), and (4) management of threats $(15 \%)$ (Table 2). Based on the papers in our literature review (Table S2b), 40\% of existing studies focused on habitat use/behavior (including habitat, distribution, and movement categories), $34 \%$ on population ecology (including population, age, and growth categories), and just $5 \%$ on threats. A relatively high number of studies focused on health $(25 \%)$, and relatively less attention has been given to the morphology $(10 \%)$ and diet $(10 \%)$ of immature life stages. Percentages of peer-reviewed studies by research topic for each species are shown in Table S2c.

Priority studies needed to improve our knowledge on 'population ecology' (Table 2) encompass demographic studies that provide information on the minimum population size, age, and survivorship needed to maintain or improve population size and stability. Additional research questions frequently selected by respon- 
Table 2. Priority research questions for immature sea turtles generated by expert elicitation. RMU: regional management unit

1 Population ecology
1.1 What is the survivorship of each stage/age-class and minimum
threshold to maintain healthy populations?
1.2 What influences survivorship and abundances, both locally and
globally?
1.3 What is the age and size at maturity?
1.4 What is the population size of juveniles?
1.5 What is the genetic and geographic origin of individuals in devel-
opmental habitats, and which RMUs do they belong to?

2 Habitat use and behavior

2.1 What is the distribution and movement of immature turtles?

2.2 What type of habitat is needed and which types are preferred?

2.3 What are the drivers of habitat selection and recruitment from pelagic post-hatchling foraging?

2.4 How do the distribution of habitat and food items correlate with juvenile densities and distributions?

2.5 How consistent is the distribution of juveniles, both spatially and temporally?

\section{Threats}

3.1 What are the key threats to juveniles in their developmental habitats, where are the threat hotspots, and how can threats be mitigated?

3.2 What are the cumulative and synergetic impacts of threats?

3.3 What are the individual and population level impacts of various threats? What is the level of impact of fisheries on juveniles and developmental habitat?

3.4 How will climate change impact individuals and their habitats?

3.5 Which genetic stocks are being threatened during the immature stage?

\section{Management}

4.1 What are the best conservation measures to mitigate threats and monitor population responses, both globally and site specifically?

4.2 What is the minimum number of populations to monitor to effectively manage and conserve juveniles of each species?

4.3 What is the minimum number of key areas needed for effectively managing RMUs and promoting population growth?

4.4 Which management strategies can be implemented to protect vulnerable populations and developmental habitats temporarily?

4.5 Are there seasonal patterns in juvenile distribution and abundance which allow for targeted management approaches?

cal characteristics of such habitats. An understanding on what drives (e.g. environmental parameters, prey distribution) the selection and preference of developmental habitats during the early life stages was also considered as a priority in this research theme. Other questions ranked were related to site fidelity and habitat specificity by different species, and whether hotspots can be predicted for immature turtles.

Under the 'threats' theme, priority studies focused on identifying the locations and characteristics of key threats to immature turtles, as well as how threats can be mitigated (e.g. Ortiz et al. 2016) (Table 2). Questions identifying the genetic stocks under higher risk from particular threats, and quantifying the individual, cumulative, and synergetic impacts of threats, especially those related to fisheries and climate change, were also identified as important. Additional questions included the impact of emerging threats such as marine pollution and identifying and tackling threats that affect turtles across multiple generations.

Even though 'management' was not considered as a research theme per se in our initial survey, critical questions in this theme were raised by multiple experts. Priority studies on 'management' (Table 2) can advance our understanding on how to efficiently monitor populations for improved management decisions and threat mitigation (Fuentes et al. 2015). Respondents also emphasized the need to identify the minimum number of pop-

dents included understanding the underlying factors that might influence population size and survivorship both at local and global scales, as well as identifying the origin of individuals in developmental habitats. Other questions that arose among the experts focused on quantifying or understanding patterns of recruitment of individuals in relation to developmental habitats.

Priority studies under 'habitat use and behavior' (Table 2) consisted of describing the spatio-temporal distribution of immature turtles, movement within and between developmental habitats, and bio-physi- ulations (at the RMU scale) and habitats needed to be protected to effectively manage threats to immature life stages. For example, the southwest Pacific green turtle RMU is comprised of 5 genetic stocks; how many of these genetic stocks need to be protected and which threats need to be managed to ensure the sustainability of the southwest Pacific green turtle RMU? In addition, respondents highlighted the need to understand whether there are patterns (e.g. seasonal, ontogenetic) in the population structure and behavior that might allow researchers to efficiently target management. 


\section{Past and future research focus by species}

Leatherback. One of the top priorities for research for this species was to understand the distribution and migration patterns of young individuals (Priority question 2.1; see Table 2 for all priority questions), as these are still largely unknown. Indeed, a comprehensive review of leatherback turtles in the pelagic realm called for increased research on the immature stage (Saba 2013). Once the biogeography of wild immature leatherback turtles is known, further studies on abundance and growth would greatly enhance the state of knowledge on this species (Priority questions 1.1, 1.3, 1.4). A pressing research topic in the Pacific Ocean is bycatch of immature leatherback turtles, given the dramatic declines of the nesting populations in the Eastern Pacific (Priority question 3.1) (Wallace et al. 2013b). The information that is available for immature individuals of this species is limited to captive growth studies (Jones et al. 2011), tracking of a small number of larger ( $>100 \mathrm{~cm}$ curved carapace length, CCL) individuals (James et al. 2005, Dodge et al. 2015), stranding records (GonzálezCarman et al. 2011, Vélez-Rubio et al. 2013, BarriosGarrido \& Montiel-Villalobos 2016, Monteiro et al. 2016), bycatch and sighting data (Eckert 2002, Casale et al. 2003, Jones et al. 2011), analysis of skeletal growth marks for a small number of captive and wild immature turtles (Avens et al. 2009), and necropsies of bycaught individuals (Work \& Balazs 2002, Casale et al. 2003). To date, there are no published studies on the diet of immature leatherback turtles.

Hawksbill. For most hawksbill populations, essential parameters such as abundance and survivorship are unknown. Future studies in population size at local scales and survival rates at regional scales (Priority questions $1.1,1.4)$, as well as the key threats in the varied developmental habitats (Priority question 3.1), would greatly increase much needed understanding to address management questions (e.g. Priority questions $4.1,4.2,4.3)$. Another research need is to further describe the origin of turtles in developmental and foraging grounds, to identify how distant these habitats are from the turtles' natal beaches (Priority question 1.5). There are extensive studies on immature stages of this species within the wider Caribbean region (e.g. León \& Diez 1999, Bjorndal \& Bolten 2010, Moncada et al. 2012, Hawkes et al. 2014, Bjorndal et al. 2016) and Australia (e.g. Limpus 1992, Jessop et al. 2004, Bell 2013), but there are large gaps remaining across the rest of the species' range. Most studies have focused on population characteristics (e.g. Blumenthal et al. 2009b, Meylan et al.
2011, Moncada et al. 2012, Strindberg et al. 2016, Llamas et al. 2017), movement and habitat use in coastal waters (e.g. van Dam \& Diez 1998, Cuevas et al. 2007, Rincon-Diaz et al. 2011, Chevis et al. 2017), and genetic composition (e.g. Velez-Zuazo et al. 2008, Blumenthal et al. 2009a, Richardson et al. 2009, Monzón-Argüello et al. 2011).

Kemp's ridley. The largest gaps in knowledge on Kemp's ecology are related to survival, growth rates, and threats for immature life stage (e.g. Priority questions 1.1, 1.2, 3.1, 3.2), especially for the western and southern Gulf of Mexico coast. A number of spatial and behavioral studies exist on the immature stage of Kemp's ridley turtles (e.g. Burke et al. 1993, Schmid et al. 2003, Schmid \& Barichivich 2005, Schmid \& Witzell 2006, Seney \& Landry 2011, Putman et al. 2013), and recent analyses have provided broadscale information regarding size-at-age and growth rates in the Gulf of Mexico (Avens et al. 2017), transatlantic movements (Witt et al. 2007, Tomás \& Raga 2008, Carreras et al. 2014) and distribution and behavior of loggerhead turtles during the oceanic developmental stage (Putman et al. 2013, Putman \& Mansfield 2015). However, many of these studies are centralized along the Gulf coast of Florida and the US east coast, and are focused on distribution or diet (e.g. Schmid et al. 2003, Witzell \& Schmid 2005).

Loggerhead. The majority of studies have focused on North Atlantic and eastern Australian populations, with substantially fewer studies conducted in the Mediterranean (Carreras et al. 2011, Clusa et al. 2014), South Atlantic, Pacific, and Indian Oceans (Hamann et al. 2013). In particular, studies that identify migratory pathways and developmental habitats of loggerhead turtles in the South Pacific Ocean (Priority questions 2,1, 2,5) could inform management strategies to mitigate bycatch (Priority questions 4.1, 4.4) in the South Eastern Pacific region (Boyle et al. 2009, Mangel et al. 2011). In the case of loggerhead turtles, this has aided in the refinement of loggerhead life history and population demography and survival models (Limpus et al. 1995, Heppel et al. 1996, Chaloupka \& Limpus 2002, Bolten 2003, Heppell et al. 2003). Dispersal pathways across the Atlantic (Bolten et al. 1998, Mansfield et al. 2014, 2017, González-Carman et al. 2016) and Indian Ocean (Dalleau et al. 2014), as well as foraging hot spots (Polovina et al. 2006, Kobayashi et al. 2008, Casale et al. 2012, Barceló et al. 2013, Seminoff et al. 2014) and post-capture behavior of bycaught individuals (Mangel et al. 2011, Arendt et al. 2012) are well documented for immature loggerhead turtles. Individuals are now known to use both 
neritic and oceanic regions as developmental habitat (McClellan \& Read 2007, Casale et al. 2008a, Mansfield et al. 2009, McClellan et al. 2010, Peckham et al. 2011, Mansfield \& Putman 2013, Ramirez et al. 2015), and there is increasing evidence for variability in the timing, growth, and 'flexibility' in the transition between oceanic and neritic habitat (Ramirez et al. 2015, 2017, Turner-Tomaszewicz et al. 2015, 2018).

Green. Literature describing the bio-physical characteristics of developmental and foraging habitats are limited for immature green turtles (Priority questions 2.2, 2.4) (Witherington et al. 2012). Immature green turtles have been studied across all ocean basins, with similar efforts in the Atlantic and Pacific Oceans. Recent research has primarily focused upon movement in foraging areas (Hart \& Fujisaki 2010, Hazel et al. 2013, Williams et al. 2017, Williard et al. 2017), genetics (Bjorndal \& Bolten 2008, Jensen et al. 2016a,b, 2018, Naro-Maciel et al. 2017), diet preferences, and trophic levels showing an ontogenetic shift from omnivore to herbivore (Bjorndal 1997, Fuentes et al. 2006, Cardona et al. 2010, González-Carman et al. 2012a, Vander Zanden et al. 2013a,b, Morais et al. 2014, Gama et al. 2016, Vélez-Rubio et al. 2018), growth rates (Limpus \& Chaloupka 1997, Bjorndal et al. 2000, 2017, Zug et al. 2002, Kubis et al. 2009, Goshe et al. 2010, Avens et al. 2012, Lenz et al. 2017), health assessments (e.g. fibropapillomatosis; Coberley et al. 2001, dos Santos et al. 2010, Hirama et al. 2014, Santos et al. 2015, Jones et al. 2016, Balladares et al. 2017), and the effect of human activities (e.g. tourism) on the health and behavior of sea turtles (Stewart et al. 2016). Most of these studies have focused on larger immature turtles (>45 cm CCL). A large knowledge gap still exists for individuals $<45 \mathrm{~cm}$ CCL (Goshe et al. 2010, Avens et al. 2012, González-Carman et al. 2012a, Putman \& Mansfield 2015).

Olive ridley. While minimal research has been done on the immature stage of olive ridley turtles, this species is considered to be the most numerous of all sea turtle populations and is of lower conservation concern relative to the other species (AbreuGrobois \& Plotkin 2008). However, identifying developmental habitats of olive ridley turtles (Priority question 2.1) is critical and necessary to enable studies on the population structure and trends of this species. The lack of knowledge can be attributed to the relatively low encounter rate of this species in the wild across all ocean basins. The few published studies are largely based on records from fisheries bycatch, and descriptions of movement patterns of released turtles (Polovina et al. 2004) and the mortality of turtles from direct harvest and bycatch (Koch et al. 2006).

Flatback. With the exception of occasional bycatch and stranding records, no studies have been published on wild-caught immature flatback turtles. Conceiving methodologies that facilitate future research into this data gap could help identify developmental habitats used by cryptic life stages (Priority question 2.1), which would be a significant advancement to understand the ecology of both olive ridley and flatback turtles. Studies on the diving and swimming behavior of reared flatback hatchlings suggest that the species inhabits deep, turbid waters with difficult access for researchers (Salmon et al. 2009, 2010, 2016, Wyneken et al. 2010). Computational simulations of the dispersal of immature flatback turtles have shed light on potential hotspot areas where turtles might aggregate (Hamann et al. 2011, Wildermann et al. 2017); these areas could serve as initial locations to carry out surveys targeted at identifying potential developmental areas.

\section{Barriers}

Respondents provided 28 unique responses on the barriers which hinder the development of research on immature sea turtles. The key barriers that have hindered the advancement of this research, as perceived by the respondents, were: limited support capacity (e.g. lack of skills or lack of external interest for support; $42 \%$ ), funding issues (27\%), data paucity $(10 \%)$, limited sharing/collaboration (10\%), technological issues (7\%), and accessibility constraints (5\%).

Among the individual barriers, lack of resources (theme = funding issues) was ranked as the most significant, followed by lack of prioritization (theme = limited support capacity), research cost (theme = funding issues), and political/donor interest (theme = limited support capacity). The MCA revealed several patterns in the responses linked to the barriers. Respondents with 6 to $10 \mathrm{yr}$ of experience mostly considered the lack of capacity/skills to be the most important barrier, while more experienced respondents (11 to $21 \mathrm{yr}$ of experience) considered accessibility constraints and lack of baseline data to be more important (Fig. 3e,f). In addition, most respondents that have worked in the Pacific and Indian regions highlighted the need for more long-term and baseline data, while respondents working in the Atlantic and Mediterranean regions considered the lack of funding as the main barrier (Fig. 3a,e). 


\section{Limitations of the study}

Expert elicitation is commonly used to discuss and identify critical knowledge gaps and research needs for several species, including marine megafauna (e.g. Hamann et al. 2010, Hays et al. 2016, Jeffers \& Godley 2016, Rees et al. 2016). It can be challenging to design comprehensive surveys that allow depiction of how the experience of each respondent influences their perceptions of a specific topic or issue. In our study, we aimed to explore this issue. However, caution needs to be taken when interpreting our results relating to previous experience of the respondents, since we considered the general experience (years of experience, species, and regions where they have worked) but were not able to tease out the extent to which their experiences (e.g. assuming different roles, or working with different species or regions throughout their professional career) influenced their responses. For example, one respondent might have $20 \mathrm{yr}$ of experience, of which $15 \mathrm{yr}$ were dedicated to green turtles in the Caribbean and 5 yr to flatback turtles in Australia; in such cases, we assumed their experience with each species and region would have the same weight or importance. Future surveys could look at depicting the degree to which previous experience drives responses, and how the perceptions of respondents that work with multiple species and regions compare to those focused on a single species or region. Another limitation of our study was that multiple research topics are inherently interlinked to each other, leading to potential double or triple counting of broader research topics. For example, age and growth are related to population ecology, and distribution and movement to habitat ecology. The same overlap applies for the individual barriers. For example, lack of sufficient funding is linked to lack of donor interest (herein considered as support constraint). The perception of the needs by respondents will depend on the amount and degree of detail of existing knowledge for a particular species or region. For the purposes of this study, we considered it necessary to segregate research topics and barriers to allow for prioritization of specific needs as viewed by each respondent. In addition, another challenge in expert elicitation is having a sound representation of respondents with different backgrounds and experience. In our study, while most RMUs were represented by the respondents, there was a lack of respondents working in the Indian Ocean. The latter could have biased the trends in our analysis, which showed the Indian Ocean as one of the regions most in need of further research on immature sea turtles. Notwithstanding these limitations, we feel the summarized responses and analysis of the data provide an accurate picture of the current priority knowledge needs for juvenile sea turtles across their range.

\section{DISCUSSION}

This study provides an indication of the current state of affairs, based on expert opinion, on the needs and priorities for future research on immature sea turtles. Major knowledge gaps remain for leatherback and hawksbill turtles, and for all species in the Indian, South Pacific, and South Atlantic Oceans. In terms of research themes, experts perceived that studies in population ecology, namely survivorship and demographic studies, should be prioritized. In addition, our results showed that the researchers' experience with the species they worked with did not influence the pattern of their responses regarding research and barrier priorities, suggesting that the respondents provided a reflection of the current gaps and priority research needs. According to the experts' point of view, lack of funding and support capacity (e.g. lack of skills or lack of external interest for support) are the primary barriers and challenges to advance research on immature sea turtles.

The current state of knowledge on immature stages of sea turtles was considered to be still developing by the experts in this study. We defined this as an understanding of basic foundations and principles with room to improve confidence in ecological data. Given that the body of knowledge on immature sea turtles has increased for over $40 \mathrm{yr}$, it is surprising that the field is still considered to be developing. The disparity between the perception of established and early career researchers regarding the current state of knowledge might be attributed to the 'shifting baselines' syndrome, in which different generations have different perceptions on the current status of reality and the degree to which that reality has changed (Pauly 1995, Bjorndal \& Bolten 2003). Nevertheless, while many of the challenges faced by researchers in the early years of sea turtle research are no longer obstacles (e.g. lack of knowledge on distribution of immature turtles), many others still persist (e.g. researchers' skills and resources to find or capture turtles, financial support) and have likely hindered advancement of this field. 


\section{Establishing research priorities for immature stages}

The research priorities identified in this study (Table 2) can be grouped under 2 main themes: (1) the need to increase studies on population ecology and habitat use/behavior; and (2) applied conservation research, such as on threats and management. Understanding population dynamics of immature sea turtles is especially important given that immature individuals constitute the major proportion of a population (Frazer 1986, Crouse et al. 1987, Heppel et al. 1996, Heppell et al. 2003, Casale et al. 2015). Population trends of sea turtles are largely estimated with only one portion of a population: adult females. Thus, there is a need to advance our ability to effectively determine sea turtle population trends by monitoring trends in abundance for other life-stages, such as immature turtles and adult males. Moreover, immature survival can have a significant effect upon population growth and reproductive potential (Andrewartha \& Birch 1954, Crowder et al. 1994, Heppel et al. 1996, Gaillard et al. 1998, Musick 1999, Mazaris et al. 2005, Ezard et al. 2006, Finkelstein et al. 2010), but can be difficult to detect and understand as it occurs. Thus, efforts towards developing techniques to quantify and monitor immature survival can provide valuable information to comprehensively assess population trends.

In addition, knowledge on how individuals and populations use space over time can be fundamental to identify critical habitats, resources, migratory pathways (Musick \& Limpus 1997, Bolten 2003, Meylan et al. 2011), baseline and shifts in growth rates (Diez \& van Dam 2002, Bjorndal et al. 2013, 2016, 2017, Murakawa \& Snover 2018), as well as the cumulative impacts of threats (Bolten et al. 2011) and areas of refuge (Maxwell et al. 2013, Halpern et al. 2015). For example, cumulative survival can be influenced by life stage duration, with varying exposure to stage- and habitat-specific threats (Frazer 1986, Sasso \& Epperly 2007, Turner-Tomaszewicz et al. 2015, Vélez-Rubio et al. 2018). In addition, building a strong ecological baseline will provide better and more efficient opportunities to tackle sudden catastrophes and threats, such as the 2010 BP Deepwater Horizon oil spill in the Gulf of Mexico (Bjorndal et al. 2011). While more research has focused on diet, health, and morphology of immature sea turtles, there is still room to improve our knowledge in such topics. These areas provide basic information on the livelihoods of individuals and an understanding of normal versus abnormal characteristics and/or param- eters, which in turn can identify detrimental effects of different threats on the physiology and well-being of individuals.

Research priorities related to applied conservation research encompass the identification and quantification of threats (Bolten et al. 2011), as well as the development of effective mitigation techniques (Wallace et al. 2013a, Jourdan \& Fuentes 2015, Rees et al. 2016). In previous studies, Hamann et al. (2010) and Rees et al. (2016) identified threats as a priority research topic for all life stages of sea turtles. In our study, climate change emerged as one of the focus areas under this category. Only a few studies have addressed this for immature turtles: Jensen et al. (2018) investigated immature turtle stocks to understand sex ratios of different age classes. Pilcher et al. (2015) investigated similar impacts of climate on immature turtles in the Arabian Gulf. This is a rapidly developing field, and the use of sexing techniques for at-sea populations is likely to expand substantially in the future, particularly in climate-challenged regions (Pilcher et al. 2015, Jensen et al. 2018).

Fisheries also emerged as an important threat category for further research. Immature sea turtles of all species interact with fishing gear, and quantitative assessments of impacts of those interactions are lacking for many species and populations (Kotas et al. 2004, Lewison et al. 2004, Garrison et al. 2009, Ishihara et al. 2011). As a result, current conservation and management decisions for sea turtles interacting with fishing gear are largely based on 'expert opinion' (see Ryder et al. 2006, Stacy et al. 2016). There are estimates on post-interaction mortality for loggerhead turtles in longline fisheries (Sasso \& Epperly 2007, Casale et al. 2008b, Álvarez de Quevedo et al. 2013), but research on leatherback turtles or the effects of hooking locations is limited (i.e. which part of the turtle's body; Santos et al. 2012, Stokes et al. 2012). Post-interaction mortality estimates for net and trawl fisheries, including those equipped with turtle excluder devices, would be of great value to managers and conservation efforts for sea turtle species. In addition to estimating mortality rates, further studies can focus on the sub-lethal impacts on sea turtles as a result of fishery interactions (Swimmer et al. 2006), and developing fishing gear and fishing methods that reduce the incidental capture of sea turtles. In the context of legal and illegal harvest of sea turtles, it is presumed that the scale of take in legal fisheries is comparable to that of bycatch, and the scale of take in illegal fisheries is likely to be even larger (Humber et al. 2014). While some efforts have been made to quantify and assess the impact of 
immature sea turtle harvest (Stringell et al. 2013), further studies in these topics can inform management of legal fisheries (e.g. closure dates/areas, size limits) and refinement of national and international legal frameworks.

Prioritization of research in different regions in this study is consistent with other assessments for all life stages. For example, Wallace et al. (2010b) identified that several of the Indian Ocean sea turtle RMUs have the highest levels of uncertainty (lack of information). Prioritizing research in the Indian Ocean region is of special significance, given that it is a critical area of concern for sea turtles because of the high rate of bycatch and illegal fishing (Riskas et al. 2018, Temple et al. 2018). Across all regions, immature turtles are also increasingly facing local and global threats such as plastic pollution (Boyle et al. 2009, González-Carman et al. 2014, Santos et al. 2015, Nelms et al. 2016a, Schuyler et al. 2016, Duncan et al. 2017, Vélez-Rubio et al. 2018), seismic surveys (Nelms et al. 2016b), and port and dredging activities (Goldberg et al. 2015, Gama et al. 2016). Furthermore, the cumulative impact of anthropogenic stressors on oceanic environments is increasing at multiple sites within the Indian Ocean (e.g. East African Coral Coast, Seychelles), South Pacific (e.g. Coral Sea, New Caledonia), and South Atlantic (e.g. St. Helena and Ascension Islands, Northeastern Brazil) (Halpern et al. 2015), and little is known about the cumulative impacts of threats to marine turtles in these regions. This overlap between emerging and increasing threats with the regions where more research is lacking should be carefully considered and addressed. The latter is of special relevance when considering that these are regions frequented by mixed stocks (i.e. different genetic origins) of immature sea turtles (Bass et al. 2006, Nishizawa et al. 2013, Cazabon-Mannette et al. 2016).

The body of knowledge on the ecology of immature loggerhead and green turtles is considerably more advanced relative to that of other species (i.e. leatherback, olive ridley, and flatback turtles). Some of the populations with limited information are also considered conservation priorities (e.g. leatherback and hawksbill turtles in the Eastern Pacific Ocean, Wallace et al. 2011), which renders research both timesensitive and time-constrained. In such cases, tradeoffs between obtaining baseline information and tackling ongoing and increasing threats may be required. In this sense, both research and conservation needs must be assessed on a case-to-case basis, in order for them to align with regional ecological, socio-cultural, economic, and political context. The management of marine resources can thus be particularly challenging, and there are several debates on topics such as prioritization approaches, sustainable use, cost-benefit, desired outcomes, and spatial scales which lead to uncertainty on which approaches to use and how to prioritize them (González-Carman et al. 2012b, 2015, Fuentes et al. 2015, 2016, Klein et al. 2017). Because of this, one approach that may prove beneficial is the development of stage-specific management strategies (Klein et al. 2017). Indeed, in areas where immature and adult turtles coincide, such strategies may provide conservation dividends to more than a single life stage.

\section{Current barriers hindering research on immature stages}

Our study identified lack of support capacity (i.e. lack of existing capacity and/or external interest) and lack of funding as the most significant barriers hindering the advancement of research on immature sea turtles. Strategies to overcome these barriers will vary greatly among regions and for specific species. Specific strategies will depend on the ability to bridge research and conservation needs with sociocultural, economic, and political priorities at both local and regional scales. However, adopting some of the practices identified below may reduce some overarching and common obstacles.

Overcoming lack of funding and limited support capacity. Attracting corporate and/or philanthropic funding for sea turtle research and management, or exploring long-term funding mechanisms that come through biodiversity offsets and blue economy schemes was suggested as a strategy to overcome lack of funding. In addition, some funding opportunities may arise from environmental impacts that elevate needs to imperatives, during which knowledge gaps can be promptly addressed to mitigate immediate and future impacts (e.g. the funding available for the restoration of the Gulf of Mexico from the Deepwater Horizon oil spill; Deepwater Horizon Natural Resource Damage Assessment Trustees 2016, McDonald et al. 2017, Mitchelmore et al. 2017, Wallace et al. 2017). An important step to ensure that research will inform management outcomes is to build research into the business planning framework of those agencies with responsibilities for managing sea turtles (González-Carman et al. 2012b, 2015, Fuentes et al. 2016, Klein et al. 2017). This is achieved by clear/improved communication between scientists/academics and managers, 
ensuring that the research and conservation priorities are enriched through feedback loops. In addition, the prioritization efforts undertaken in this study could be used by funding agencies to better target use of limited funds.

Overcoming accessibility constraints. Considering that access to immature turtles is one of the largest hindrances to advancing knowledge of this life stage, incorporating novel ways to partner with existing oceanic platforms (e.g. high seas fisheries vessels, ocean clean-up organizations, tourism vendors and groups) could potentially provide access to oceanic immature turtles. Similarly, entities with vessels (e.g. private sector, fishers, tourist service providers) or platforms (e.g. offshore oil and gas platforms, surveillance platforms) may provide a viable means for scientists to gain access to more remote areas.

Improving cooperation and data sharing. Metastudies incorporating data from multiple regions and/or species collected by different organizations can substantially increase the power and significance of research (National Research Council 2010, Wallace et al. 2010a, 2011, Bjorndal et al. 2013, 2016, 2017, Fossette et al. 2014, Mazaris et al. 2018). This is of importance given that immature turtles are such a large component of the population, and large sample sizes spanning multiple years are needed to draw strong inferences. Thus, establishing collaborations with groups or agencies that have long-term data on immature sea turtles can facilitate data analyses and publication. For instance, there may be valuable databases with fisheries managers on bycaught sea turtles that may provide greater insight into behavior and migration (Riskas et al. 2016). It may also be possible to enlist the help of volunteers or citizen scientists to generate data that can contribute to the knowledge base of immature sea turtles (e.g. Hof et al. 2017, Williams et al. 2017). Similarly, pooling resources and seeking funding with other disciplines might increase the capacity to collect more data and increase field-presence of researchers (e.g. taking part in oceanographic cruises, collaborating with mammal/bird/shark researchers). From a management standpoint, increased international cooperation (e.g. through multi-lateral environmental agreements and establishment of marine protected areas, particularly in the high seas; Wedding et al. 2016) would provide data which often show trans-boundary movements; such information can be used more effectively in management efforts, and thus may be more likely to be supported.

Further sources of information on immature sea turtles might be found by considering unpublished data housed in various facilities and institutions. In developing countries/low capacity regions (e.g. Indian Ocean, Caribbean), it is important to use local ecological knowledge and integrate the community into monitoring projects (Stephenson et al. 2016, Hamel et al. 2018, Barrios-Garrido et al. 2018). For example, encouraging the access and sharing of data from reporting schemes with small-scale fishers could shed light on occurrence, distribution, hotspots, and threats to immature sea turtles. Also, a way to facilitate knowledge accessibility is to foster data and experience sharing through databases or web portals (e.g. seaturtle.org, Climate Adaptation Knowledge Exchange: cakex.org), so new projects can learn from both success and failure stories, leading to potential savings in time, resources, and efforts.

Incorporating new technologies. Further development and application of new approaches, such as integrating skeletal growth increment and stable isotope and/or trace element analyses have the potential to provide individual-specific and populationwide information regarding habitat use and foraging ecology over long time frames (e.g. Avens et al. 2013, Ramirez et al. 2015, 2017, Turner Tomaszewicz et al. 2015, 2018). Technological developments are also making in-water studies more relevant and cost attractive. Expansion of genetic sequences and methods allows greater differentiation amongst populations (Tikochinski et al. 2018). Endocrinology and laparoscopy (in particular) are paving the way for rapid understanding of age or stage class sex-ratios. Such contextual information allows for clearer understanding of age-specific mortality and of the impacts of climate change (Jensen et al. 2018). Miniaturization of tracking devices and the advent of solar-powered units and GPS technology use in tracking are increasing the potential for understanding foraging immature turtle stocks (Putman \& Mansfield 2015, Mansfield et al. 2017). Advances in unmanned aerial systems also increase the potential to obtain better abundance estimates and behavioral data for sea turtles in coastal foraging areas (Bevan et al. 2015, Sykora-Bodie et al. 2017, Rees et al. 2018). Further technological developments may open up this field of study even further.

Acknowledgements. This research was conducted under Florida State University Ethics Approval HSC Number 2015.16178. Any use of trade, firm, or product names is for descriptive purposes only and does not imply endorsement by the U.S. Government. We appreciate the editorial assistance provided by Daniel Sloane, Janine Powell, and Michael Cherkiss. We are also thankful for the support and comments provided by the editors and reviewers. 


\section{LITERATURE CITED}

Abreu-Grobois A, Plotkin PT (2008) Lepidochelys olivacea. IUCN Red List of Threatened Species: e.T11534A3292503

Álvarez de Quevedo I, San Félix M, Cardona L (2013) Mortality rates in by-caught loggerhead turtle Caretta caretta in the Mediterranean Sea and implications for the Atlantic populations. Mar Ecol Prog Ser 489:225-234

Andrewartha HG, Birch LC (1954) The distribution and abundance of animals. University of Chicago Press, Chicago, IL

Arendt MD, Segars AL, Byrd JI, Boynton J and others (2012) Seasonal distribution patterns of juvenile loggerhead sea turtles (Caretta caretta) following capture from a shipping channel in the Northwest Atlantic Ocean. Mar Biol 159:127-139

Auerbach CF, Silverstein LB (2003) Qualitative data: an introduction to coding and analysis, Vol 1. New York University Press, New York, NY

Avens L, Taylor JC, Goshe LR, Jones TT, Hastings M (2009) Use of skeletochronological analysis to estimate the age of leatherback sea turtles Dermochelys coriacea in the western North Atlantic. Endang Species Res 8:165-177

Avens L, Goshe LR, Harms CA, Anderson ET and others (2012) Population characteristics, age structure, and growth dynamics of neritic juvenile green turtles in the northeastern Gulf of Mexico. Mar Ecol Prog Ser 458: 213-229

Avens L, Goshe LR, Pajuelo M, Bjorndal KA and others (2013) Complementary skeletochronology and stable isotope analyses offer new insight into juvenile loggerhead sea turtle oceanic stage duration and growth dynamics. Mar Ecol Prog Ser 491:235-251

Avens L, Goshe LR, Coggins L, Shaver DJ, Higgins B, Landry AM Jr, Bailey R (2017) Variability in age and size at maturation, reproductive longevity, and long-term growth dynamics for Kemp's ridley sea turtles in the Gulf of Mexico. PLOS ONE 12:e0173999

Balazs GH (1980) Synopsis of biological data on the green turtle in the Hawaiian Islands. NOAA Tech Memo NOAATM-NMFS-SWFC-7

Balladares C, Marin E, Espinoza-Rodríguez N, Barrios-Garrido H (2017) Prevalence of fibropapillomatosis on stranded sea turtles in the Venezuelan coast. Rev Bio Cienc 4:04.04.02

Barceló C, Domingo A, Miller P, Ortega L and others (2013) High-use areas, seasonal movements and dive patterns of juvenile loggerhead sea turtles in the Southwestern Atlantic Ocean. Mar Ecol Prog Ser 479:235-250

Barrios-Garrido H, Montiel-Villalobos MG (2016) Strandings of leatherback turtles (Dermochelys coriacea) along the western and southern coast of the Gulf of Venezuela. Herpetol Conserv Biol 11:244-252

Barrios-Garrido H, Palmar J, Wildermann N, Diedrich A, Hamann M (2018) Marine turtles presence in the traditional pharmacopoeia, cosmovision, and beliefs of Wayuú Indigenous people. Chelonian Conserv Biol 17: in press

Bass AL, Epperly SP, Braun-McNeill J (2006) Green turtle (Chelonia mydas) foraging and nesting aggregations in the Caribbean and Atlantic: impact of currents and behavior on dispersal. J Hered 97:346-354

Bell I (2013) Algivory in hawksbill turtles: Eretmochelys imbricata food selection within a foraging area on the Northern Great Barrier Reef. Mar Ecol 34:43-55
Bevan E, Wibbels T, Najera BMZ, Martinez MAC and others (2015) Unmanned aerial vehicles (UAVs) for monitoring sea turtles in near-shore waters. Mar Turtle Newsl 145: $19-22$

Biernacki P, Waldorf D (1981) Snowball sampling. Problems and techniques of chain referral sampling. Sociol Methods Res 10:141-163

Bjorndal K (1997) Foraging ecology and nutrition of sea turtles. In: Lutz PL, Musick JA (eds) The biology of sea turtles, Vol 1. CRC Press, New York, NY, p 199-231

Bjorndal KA, Bolten AB (2003) From ghosts to key species: restoring sea turtle populations to fulfill their ecological roles. Mar Turtle Newsl 100:16-21

* Bjorndal KA, Bolten AB (2008) Annual variation in source contributions to a mixed stock: implications for quantifying connectivity. Mol Ecol 17:2185-2193

* Bjorndal KA, Bolten AB (2010) Hawksbill sea turtles in seagrass pastures: success in a peripheral habitat. Mar Biol 157:135-145

Bjorndal KA, Bolten AB, Chaloupka MY (2000) Green turtle somatic growth model: evidence for density dependence. Ecol Appl 10:269-282

Bjorndal KA, Bowen BW, Chaloupka M, Crowder LB and others (2011) Better science needed for restoration in the Gulf of Mexico. Science 331:537-538

* Bjorndal KA, Schroeder BA, Foley AM, Witherington BE and others (2013) Temporal, spatial, and body size effects on growth rates of loggerhead sea turtles (Caretta caretta) in the Northwest Atlantic. Mar Biol 160:2711-2721

* Bjorndal KA, Chaloupka M, Saba VS, Diez CE and others (2016) Somatic growth dynamics of West Atlantic hawksbill sea turtles: a spatio temporal perspective. Ecosphere 7:e01279

* Bjorndal KA, Bolten AB, Chaloupka M, Saba VS and others (2017) Ecological regime shift drives declining growth rates of sea turtles throughout the West Atlantic. Glob Change Biol 23:4556-4568

*Bumenthal JM, Abreu-Grobois FA, Austin TJ, Broderick AC and others (2009a) Turtle groups or turtle soup: dispersal patterns of hawksbill turtles in the Caribbean. Mol Ecol 18:4841-4853

* Blumenthal JM, Austin TJ, Bell CDL, Bothwell JB and others (2009b) Ecology of hawksbill turtles, Eretmochelys imbricata, on a western Caribbean foraging ground. Chelonian Conserv Biol 8:1-10

Bolten AB (2003) Variation in sea turtle life history patterns: neritic vs. oceanic developmental stages. In: Lutz PL, Musick J, Wyneken J (eds) The biology of sea turtles, Vol 2. CRC Press, Boca Raton, FL, 243-257

*B Bolten AB, Bjorndal KA, Martins HR, Dellinger T, Biscoito MJ, Encalada SE, Bowen BW (1998) Transatlantic developmental migrations of loggerhead sea turtles demonstrated by mtDNA sequence analysis. Ecol Appl $8: 1-7$

* Bolten AB, Crowder LB, Dodd MG, MacPherson SL and others (2011) Quantifying multiple threats to endangered species: an example from loggerhead sea turtles. Front Ecol Environ 9:295-301

* Boyle M, FitzSimmons N, Limpus C, Kelez S, Velez-Zuazo X, Waycott M (2009) Evidence for transoceanic migrations by loggerhead sea turtles in the southern Pacific Ocean. Proc R Soc B 276:1993-1999

Burke V, Morreale S, Rhodin A (1993) Lepidochelys kempii (Kemp's ridley sea turtle) and Caretta caretta (loggerhead sea turtle) diet. Herpetol Rev 24:31-32 
Burt C (1950) The factorial analysis of qualitative data. Br J Stat Psychol 3:166-185

Cardona L, Campos P, Levy Y, Demetropoulos A, Margaritoulis D (2010) Asynchrony between dietary and nutritional shifts during the ontogeny of green turtles (Chelonia mydas) in the Mediterranean. J Exp Mar Biol Ecol 393:83-89

* Carreras C, Pascual M, Cardona L, Marco A and others (2011) Living together but remaining apart: Atlantic and Mediterranean loggerhead sea turtles (Caretta caretta) in shared feeding grounds. J Hered 102:666-677

* Carreras C, Monzón-Argüello C, López-Jurado LF, Calabuig $\mathrm{P}$ and others (2014) Origin and dispersal routes of foreign green and Kemp's ridley turtles in Spanish Atlantic and Mediterranean waters. Amphib-Reptil 35: 73-86

* Casale P (2015) Caretta caretta (Mediterranean subpopulation). The IUCN Red List of Threatened Species 2015: e.T83644804A83646294

Casale P, Heppell SS (2016) How much sea turtle bycatch is too much? A stationary age distribution model for simulating population abundance and potential biological removal in the Mediterranean. Endang Species Res 29: 239-254

Casale P, Nicolosi P, Freggi D, Turchetto M, Argano R (2003) Leatherback turtles (Dermochelys coriacea) in Italy and in the Mediterranean basin. Herpetol J 13:135-139

* Casale P, Abbate G, Freggi D, Conte N, Oliverio M, Argano R (2008a) Foraging ecology of loggerhead sea turtles Caretta caretta in the central Mediterranean Sea: evidence for a relaxed life history model. Mar Ecol Prog Ser 372:265-276

* Casale P, Freggi D, Rocco M (2008b) Mortality induced by drifting longline hooks and branchlines in loggerhead sea turtles, estimated through observation in captivity. Aquat Conserv 18:945-954

* Casale P, Broderick AC, Freggi D, Mencacci R, Fuller WJ, Godley BJ, Luschi P (2012) Long-term residence of juvenile loggerhead turtles to foraging grounds: a potential conservation hotspot in the Mediterranean. Aquat Conserv 22:144-154

* Casale P, Freggi D, Furii G, Vallini C and others (2015) Annual survival probabilities of juvenile loggerhead sea turtles indicate high anthropogenic impact on Mediterranean populations. Aquat Conserv 25:690-700

* Casale P, Freggi D, Paduano V, Oliverio M (2016) Biases and best approaches for assessing debris ingestion in sea turtles, with a case study in the Mediterranean. Mar Pollut Bull 110:238-249

* Cazabon-Mannette M, Browne D, Austin N, Hailey A, Horrocks J (2016) Genetic structure of the hawksbill turtle rookery and foraging aggregation in Tobago, West Indies. J Exp Mar Biol Ecol 485:94-101

Chaloupka M, Limpus C (2002) Survival probability estimates for the endangered loggerhead sea turtle resident in southern Great Barrier Reef waters. Mar Biol 140: 267-277

Chevis MG, Godley BJ, Lewis JP, Lewis JJ, Scales KL, Graham RT (2017) Movement patterns of juvenile hawksbill turtles Eretmochelys imbricata at a Caribbean coral atoll: long-term tracking using passive acoustic telemetry. Endang Species Res 32:309-319

Clusa M, Carreras C, Pascual M, Gaughran SJ and others (2014) Fine-scale distribution of juvenile Atlantic and Mediterranean loggerhead turtles (Caretta caretta) in the Mediterranean Sea. Mar Biol 161:509-519

Coberley SS, Herbst LH, Ehrhart LM, Bagley DA, Hirama S, Jacobson ER, Klein PA (2001) Survey of Florida green turtles for exposure to a disease-associated herpesvirus. Dis Aquat Org 47:159-167

Crouse DT, Crowder LB, Caswell H (1987) A stage based population model for loggerhead sea turtles and implications for conservation. Ecology 68:1412-1423

* Crowder LB, Crouse DT, Heppell SS, Martin TH (1994) Predicting the impact of turtle excluder devices on loggerhead sea-turtle populations. Ecol Appl 4:437-445

* Cuevas E, de los Ángeles Liceaga-Corre M, GarduñoAndrade M (2007) Spatial characterization of a foraging area for immature hawksbill turtles (Eretmochelys imbricata) in Yucatan, Mexico. Amphib-Reptil 28:337-346

* Dalleau M, Benhamou S, Sudre J, Ciccione S, Bourjea J (2014) The spatial ecology of juvenile loggerhead turtles (Caretta caretta) in the Indian Ocean sheds light on the 'lost years' mystery. Mar Biol 161:1835-1849

Deepwater Horizon Natural Resource Damage Assessment Trustees (2016) Deepwater Horizon oil spill: final programmatic damage assessment and restoration plan and final programmatic environmental impact statement. www.gulfspillrestoration.noaa.gov/restoration-planning/ gulf-plan

* Diez CE, van Dam RP (2002) Habitat effect on hawksbill turtle growth rates on feeding grounds at Mona and Monito Islands, Puerto Rico. Mar Ecol Prog Ser 234:301-309

Dodge KL, Galuardi B, Lutcavage ME (2015) Orientation behaviour of leatherback sea turtles within the North Atlantic subtropical gyre. Proc R Soc B 282:20143129

*dos Santos RG, Martins AS, Torezani E, Baptistotte C and others (2010) Relationship between fibropapillomatosis and environmental quality: a case study with Chelonia mydas off Brazil. Dis Aquat Org 89:87-95

* Duncan EM, Botterell ZLR, Broderick AC, Galloway TS, Lindeque PK, Nuno A, Godley BJ (2017) A global review of marine turtle entanglement in anthropogenic debris: a baseline for further action. Endang Species Res 34: 431-448

Eckert SA (2002) Distribution of juvenile leatherback sea turtle Dermochelys coriacea sightings. Mar Ecol Prog Ser 230:289-293

Ezard THG, Becker PH, Coulson T (2006) The contributions of age and sex to variation in common tern population growth rate. J Anim Ecol 75:1379-1386

Finkelstein ME, Doak DF, Nakagawa M, Sievert PR, Klavitter J (2010) Assessment of demographic risk factors and management priorities: impacts on juveniles substantially affect population viability of a long-lived seabird. Anim Conserv 13:148-156

Fossette S, Witt MJ, Miller P, Nalovic MA and others (2014) Pan-Atlantic analysis of the overlap of a highly migratory species, the leatherback turtle, with pelagic longline fisheries. Proc R Soc B 281:20133065

Frazer NB (1986) Survival from egg to adulthood in a declining population of loggerhead turtles, Caretta caretta. Herpetologica 42:47-55

Fuentes MMPB, Lawler IR, Gyuris E (2006) Dietary preferences of juvenile green turtles (Chelonia mydas) on a tropical reef flat. Wildl Res 33:671-678

Fuentes MMPB, Blackwood J, Jones B, Kim M and others (2015) A decision framework for prioritizing multiple management actions for threatened marine megafauna. Ecol Appl 25:200-214 
Fuentes MMPB, Chambers L, Chin A, Dann P and others (2016) Adaptive management of marine mega-fauna in a changing climate. Mitig Adapt Strat Glob Change 21: 209-224

Gaillard JM, Festa-Bianchet M, Yoccoz NG (1998) Population dynamics of large herbivores: variable recruitment with constant adult survival. Trends Ecol Evol 13:58-63

* Gama LR, Domit C, Broadhurst MK, Fuentes MMPB, Millar RB (2016) Green turtle Chelonia mydas foraging ecology at $25^{\circ} \mathrm{S}$ in the western Atlantic: evidence to support a feeding model driven by intrinsic and extrinsic variability. Mar Ecol Prog Ser 542:209-219

Garrison LP, Stokes L, Fairfield C (2009) Estimated bycatch of marine mammals and sea turtles in the U.S. Atlantic pelagic longline fleet during 2008. NOAA Tech Memo NMFS-SEFSC591

Godley BJ, Blumenthal JM, Broderick AC, Coyne MS, Godfrey MH, Hawkes LA, Witt MJ (2008) Satellite tracking of sea turtles: Where have we been and where do we go next? Endang Species Res 4:3-22

Goldberg DW, de Almeida DT, Tognin F, Lopez GG, Pizetta GT, Junior NdOL, Sforza R (2015) Hopper dredging impacts on sea turtles on the Northern Coast of Rio de Janeiro State, Brazil. Mar Turtle Newsl 147:16-20

* González-Carman V, Álvarez KC, Prosdocimi L, Inchaurraga $\mathrm{MC}$ and others (2011) Argentinian coastal waters: a temperate habitat for three species of threatened sea turtles. Mar Biol Res 7:500-508

González-Carman V, Falabella V, Maxwell S, Albareda D, Campagna C, Mianzan H (2012a) Revisiting the ontogenetic shift paradigm: the case of juvenile green turtles in the SW Atlantic. J Exp Mar Biol Ecol 429:64-72

* González-Carman V, Machain N, Albareda D, Mianzan H, Campagna C (2012b) Legal and institutional tools to mitigate marine turtle bycatch: Argentina as a case study. Mar Policy 36:1265-1274

*González-Carman V, Acha EM, Maxwell SM, Albareda D, Campagna C, Mianzan H (2014) Young green turtles, Chelonia mydas, exposed to plastic in a frontal area of the SW Atlantic. Mar Pollut Bull 78:56-62

* González-Carman V, Machain N, Campagna C (2015) Legal and institutional tools to mitigate plastic pollution affecting marine species: Argentina as a case study. Mar Pollut Bull 92:125-133

*González-Carman V, Bruno I, Maxwell S, Álvarez K, Albareda D, Acha EM, Campagna C (2016) Habitat use, site fidelity and conservation opportunities for juvenile loggerhead sea turtles in the Río de la Plata, Argentina. Mar Biol 163:20

Goshe LR, Avens L, Scharf FS, Southwood AL (2010) Estimation of age at maturation and growth of Atlantic green turtles (Chelonia mydas) using skeletochronology. Mar Biol 157:1725-1740

Gredzens C, Marsh H, Fuentes MMPB, Limpus CJ, Shimada T, Hamann M (2014) Satellite tracking of sympatric marine megafauna can inform the biological basis for species co-management. PLOS ONE 9:e98944

Halpern BS, Frazier M, Potapenko J, Casey KS and others (2015) Spatial and temporal changes in cumulative human impacts on the world's ocean. Nat Commun 6: 7615

Hamann M, Godfrey MH, Seminoff JA, Arthur K and others (2010) Global research priorities for sea turtles: informing management and conservation in the 21 st century. Endang Species Res 11:245-269
Hamann M, Grech A, Wolanski E, Lambrechts J (2011) Modelling the fate of marine turtle hatchlings. Ecol Model 222:1515-1521

* Hamann M, Kamrowski RL, Bodine T (2013) Assessment of the conservation status of the loggerhead turtle in the Indian Ocean and South-East Asia. IOSEA Species Assessment, Vol II. IOSEA Marine Turtle MoU Secretariat, Bangkok

*Hamel MA, Pressey RL, Evans LS, Andréfouët S (2018) The importance of fishing grounds as perceived by local communities can be undervalued by measures of socioeconomic cost used in conservation planning. Conserv Lett 11:e12352

*Hart KM, Fujisaki I (2010) Satellite tracking reveals habitat use by juvenile green sea turtles Chelonia mydas in the Everglades, Florida, USA. Endang Species Res 11:221-232

*Hart KM, Hyrenbach KD (2009) Satellite telemetry of marine megavertebrates: the coming of age of an experimental science. Endang Species Res 10:9-20

*Hawkes LA, Broderick AC, Godfrey MH, Godley BJ (2009) Climate change and marine turtles. Endang Species Res $7: 137-154$

Hawkes LA, McGowan A, Broderick AC, Gore S and others (2014) High rates of growth recorded for hawksbill sea turtles in Anegada, British Virgin Islands. Ecol Evol 4: 1255-1266

*Hays GC, Ferreira LC, Sequeira AMM, Meekan MG and others (2016) Key questions in marine megafauna movement ecology. Trends Ecol Evol 31:463-475

* Hazel J, Hamann M, Lawler IR (2013) Home range of immature green turtles tracked at an offshore tropical reef using automated passive acoustic technology. Mar Biol 160:617

*Hazen EL, Maxwell SM, Bailey H, Bograd SJ and others (2012) Ontogeny in marine tagging and tracking science: technologies and data gaps. Mar Ecol Prog Ser 457: 221-240

*Heppel SS, Limpus CJ, Crouse DT, Frazer NB, Crowder LB (1996) Population model analysis for the loggerhead sea turtle, Caretta caretta, in Queensland. Wildl Res 23: 143-161

Heppell SS, Crowder LB, Crouse DT, Epperley SP, Frazer NB (2003) Population models for Atlantic loggerheads: past, present, and future. In: Bolten $A B$, Witherington $B E$ (eds) Loggerhead sea turtles. Smithsonian Institution, Washington, DC, p 255-273

Hirama S, Ehrhart LM, Rea LD, Kiltie RA (2014) Relating fibropapilloma tumor severity to blood parameters in green turtles Chelonia mydas. Dis Aquat Org 111:61-68

Hof CAM, Smallwood E, Meager J, Bell IP (2017) First citizen-science population abundance and growth rate estimates for green sea turtles Chelonia mydas foraging in the northern Great Barrier Reef, Australia. Mar Ecol Prog Ser 574:181-191

* Humber F, Godley BJ, Broderick AC (2014) So excellent a fishe: a global overview of legal marine turtle fisheries. Divers Distrib 20:579-590

Husson F, Lê S, Pagès J (2010) Exploratory multivariate analysis by example using R. CRC Press, Boca Raton, FL

* Ishihara T, Kamezaki N, Matsuzawa Y, Iwamoto F and others (2011) Reentery [sic] of juvenile and subadult loggerhead turtles into natal waters of Japan. Curr Herpetol 30: 63-68

James MC, Ottensmeyer CA, Myers RA (2005) Identification of high-use habitat and threats to leatherback sea turtles 
in northern waters: new directions for conservation. Ecol Lett 8:195-201

Jeffers VF, Godley BJ (2016) Satellite tracking in sea turtles: How do we find our way to the conservation dividends? Biol Conserv 199:172-184

Jensen MP, Bell I, Limpus CJ, Hamann M and others (2016a) Spatial and temporal genetic variation among size classes of green turtles (Chelonia mydas) provides information on oceanic dispersal and population dynamics. Mar Ecol Prog Ser 543:241-256

Jensen MP, Pilcher N, FitzSimmons NN (2016b) Genetic markers provide insight on origins of immature green turtles Chelonia mydas with biased sex ratios at foraging grounds in Sabah, Malaysia. Endang Species Res 31: 191-201

Jensen MP, Allen CD, Eguchi T, Bell IP and others (2018) Environmental warming and feminization of one of the largest sea turtle populations in the world. Curr Biol 28: 154-159.e4

Jessop TS, Sumner JM, Limpus CJ, Whittier JM (2004) Interplay between plasma hormone profiles, sex and body condition in immature hawksbill turtles (Eretmochelys imbricata) subjected to a capture stress protocol. Comp Biochem Physiol A Mol Integr Physiol 137:197-204

Jones K, Ariel E, Burgess G, Read M (2016) A review of fibropapillomatosis in green turtles (Chelonia mydas). Vet J 212:48-57

Jones TT, Hastings MD, Bostrom BL, Pauly D, Jones DR (2011) Growth of captive leatherback turtles, Dermochelys coriacea, with inferences on growth in the wild: implications for population decline and recovery. J Exp Mar Biol Ecol 399:84-92

Jourdan J, Fuentes MMPB (2015) Effectiveness of strategies at reducing sand temperature to mitigate potential impacts from changes in environmental temperature on sea turtle reproductive output. Mitig Adapt Strat Glob Change 20:121-133

Kassambara A, Mundt F (2017) Package 'factoextra'. https:// cran.r-project.org/web/packages/factoextra/index.html

Klein CJ, Beher J, Chaloupka M, Hamann M, Limpus C, Possingham HP (2017) Prioritization of marine turtle management projects: a protocol that accounts for threats to different life history stages. Conserv Lett 10: $547-554$

Kobayashi DR, Polovina JJ, Parker DM, Kamezaki N and others (2008) Pelagic habitat characterization of loggerhead sea turtles, Caretta caretta, in the North Pacific Ocean (1997-2006): insights from satellite tag tracking and remotely sensed data. J Exp Mar Biol Ecol 356: 96-114

*Koch V, Nichols WJ, Peckham H, de la Toba V (2006) Estimates of sea turtle mortality from poaching and bycatch in Bahia Magdalena, Baja California Sur, Mexico. Biol Conserv 128:327-334

Kotas JE, dos Santos S, de Azevedo VG, Gallo BM (2004) Incidental capture of loggerhead (Caretta caretta) and leatherback (Dermochelys coriacea) sea turtles by the pelagic longline fishery off southern Brazil. Fish Bull 102: 393-399

Kubis S, Chaloupka M, Ehrhart L, Bresette M (2009) Growth rates of juvenile green turtles Chelonia mydas from three ecologically distinct foraging habitats along the east central coast of Florida, USA. Mar Ecol Prog Ser 389: 257-269

* Lê S, Josse J, Husson F (2008) FactoMineR: an R package for multivariate analysis. J Stat Softw 25:1-18

* Lee PH, Yu PLH (2013) An R package for analyzing and modeling ranking data. BMC Med Res Methodol 13:65

* Lenz AJ, Avens L, Borges-Martins M (2017) Age and growth of juvenile green turtles Chelonia mydas in the western South Atlantic Ocean. Mar Ecol Prog Ser 568:191-201

León YM, Diez CE (1999) Population structure of hawksbill turtles on a foraging ground in the Dominican Republic. Chelonian Conserv Biol 3:230-236

* Lewison RL, Freeman SA, Crowder LB (2004) Quantifying the effects of fisheries on threatened species: the impact of pelagic longlines on loggerhead and leatherback sea turtles. Ecol Lett 7:221-231

Kewison R, Oro D, Godley BJ, Underhill L and others (2012) Research priorities for seabirds: improving conservation and management in the 21st century. Endang Species Res 17:93-121

KLimpus CJ (1992) The hawksbill turtle, Eretmochelys imbricata, in Queensland: population structure within a southern Great Barrier Reef feeding ground. Wildl Res 19: 489-505

* Limpus CJ, Chaloupka M (1997) Nonparametric regression modelling of green sea turtle growth rates (southern Great Barrier Reef). Mar Ecol Prog Ser 149:23-34

Limpus C, Couper P, Read M (1995) The loggerhead turtle, Caretta caretta, in Queensland: population structure in a warm temperate feeding area. Oceanogr Lit Rev 9:767

KLlamas I, Flores EE, Abrego ME, Seminoff JA and others (2017) Distribution, size range and growth rates of hawksbill turtles at a major foraging ground in the eastern Pacific Ocean. Lat Am J Aquat Res 45:597-605

Lutz PL, Musick JA (eds) (1997) The biology of sea turtles, Vol 1. CRC Press, Boca Raton, FL

Lutz PL, Musick JA, Wyneken J (eds) (2003) The biology of sea turtles, Vol 2. CRC Press, Boca Raton, FL

* Mangel JC, Alfaro-Shigueto J, Witt MJ, Dutton PH, Seminoff JA, Godley BJ (2011) Post-capture movements of loggerhead turtles in the southeastern Pacific Ocean assessed by satellite tracking. Mar Ecol Prog Ser 433: 261-272

Mansfield KL, Putman NF (2013) Oceanic habits and habitats: Caretta caretta. In: Wyneken J, Lohmann KJ, Musick JA (eds) Biology of sea turtles, Vol 3. CRC Press, Boca Raton, FL, p 189-211

Mansfield KL, Saba VS, Keinath JA, Musick JA (2009) Satellite tracking reveals a dichotomy in migration strategies among juvenile loggerhead turtles in the Northwest Atlantic. Mar Biol 156:2555-2570

* Mansfield KL, Wyneken J, Rittschof D, Walsh M, Lim CW, Richards PM (2012) Satellite tag attachment methods for tracking neonate sea turtles. Mar Ecol Prog Ser 457: 181-192

*Mansfield KL, Wyneken J, Porter WP, Luo J (2014) First satellite tracks of neonate sea turtles redefine the 'lost years' oceanic niche. Proc R Soc B 281:20133039

*Mansfield KL, Mendilaharsu ML, Putman NF, dei Marcovaldi MAG and others (2017) First satellite tracks of South Atlantic sea turtle 'lost years': seasonal variation in trans-equatorial movement. Proc R Soc B 284:20171730

Kaxwell SM, Hazen EL, Bograd SJ, Halpern BS and others (2013) Cumulative human impacts on marine predators. Nat Commun 4:2688

* Mazaris AD, Fiksen Ø, Matsinos YG (2005) Using an individual-based model for assessment of sea turtle population viability. Popul Ecol 47:179-191 
Mazaris AD, Schofield G, Gkazinou C, Almpanidou V, Hays GC (2017) Global sea turtle conservation successes. Sci Adv 3:e1600730

Mazaris AD, Gkazinou C, Almpanidou V, Balazs G (2018) The sociology of sea turtle research: evidence on a global expansion of co-authorship networks. Biodivers Conserv 27:1503-1516

Mazor T, Levin N, Possingham HP, Levy Y, Rocchini D, Richardson AJ, Kark S (2013) Can satellite-based night lights be used for conservation? The case of nesting sea turtles in the Mediterranean. Biol Conserv 159:63-72

McClellan CM, Read AJ (2007) Complexity and variation in loggerhead sea turtle life history. Biol Lett 3:592-594

McClellan CM, Braun-McNeill J, Avens L, Wallace BP, Read AJ (2010) Stable isotopes confirm a foraging dichotomy in juvenile loggerhead sea turtles. J Exp Mar Biol Ecol $387: 44-51$

McDonald TL, Schroeder BA, Stacy BA, Wallace BP and others (2017) Density and exposure of surface-pelagic juvenile sea turtles to Deepwater Horizon oil. Endang Species Res 33:69-82

* Meylan PA, Meylan AB, Gray JA (2011) The ecology and migrations of sea turtles 8 . Tests of the developmental habitat hypothesis. Bull Am Mus Nat Hist 357:1-70

Mitchelmore CL, Bishop CA, Collier TK (2017) Toxicological estimation of mortality of oceanic sea turtles oiled during the Deepwater Horizon oil spill. Endang Species Res 33: 39-50

Moncada FG, Hawkes LA, Fish MR, Godley BJ and others (2012) Patterns of dispersal of hawksbill turtles from the Cuban shelf inform scale of conservation and management. Biol Conserv 148:191-199

* Monteiro DS, Estima SC, Gandra TBR, Silva AP and others (2016) Long-term spatial and temporal patterns of sea turtle strandings in southern Brazil. Mar Biol 163:247

Monzón-Argüello C, Loureiro NS, Delgado C, Marco A, Lopes JM, Gomes MG, Abreu-Grobois FA (2011) Príncipe island hawksbills: genetic isolation of an eastern Atlantic stock. J Exp Mar Biol Ecol 407:345-354

Morais RA, dos Santos RG, Longo GO, Yoshida ETE, Stahelin GD, Horta PA (2014) Direct evidence for gradual ontogenetic dietary shift in the green turtle, Chelonia mydas. Chelonian Conserv Biol 13:260-266

Murakawa SKK, Snover ML (2018) Impact of exceptional growth rates on estimations of life-stage duration in Hawaiian green sea turtles. Endang Species Res 35: 181-193

Musick JA (ed) (1999) Life in the slow lane: ecology and conservation of long-lived marine animals. Am Fish Soc Symp 23. American Fisheries Society, Bethesda, MD

Musick JA, Limpus CJ (1997) Habitat utilization and migration in juvenile sea turtles. In: Lutz PL, Musick JA (eds) The biology of sea turtles, Vol. 1. CRC Press, Boca Raton, FL, p 137-163

Naro-Maciel E, Hart KM, Cruciata R, Putman NF (2017) DNA and dispersal models highlight constrained connectivity in a migratory marine megavertebrate. Ecography 40:586-597

National Research Council (2010) Assessment of sea-turtle status and trends: integrating demography and abundance. National Academies Press, Washington, DC

Nelms SE, Duncan EM, Broderick AC, Galloway TS and others (2016a) Plastic and marine turtles: a review and call for research. ICES J Mar Sci 73:165-181

Nelms SE, Piniak WED, Weir CR, Godley BJ (2016b) Seismic surveys and marine turtles: an underestimated global threat? Biol Conserv 193:49-65

Nishizawa H, Naito Y, Suganuma H, Abe O and others (2013) Composition of green turtle feeding aggregations along the Japanese archipelago: implications for changes in composition with current flow. Mar Biol 160: 2671-2685

Ortiz N, Mangel JC, Wang J, Alfaro-Shigueto J and others (2016) Reducing green turtle bycatch in small-scale fisheries using illuminated gillnets: the cost of saving a sea turtle. Mar Ecol Prog Ser 545:251-259

*Pauly D (1995) Anecdotes and the shifting baseline syndrome of fisheries. Trends Ecol Evol 10:430

* Peckham SH, Maldonado-Diaz D, Tremblay Y, Ochoa R and others (2011) Demographic implications of alternative foraging strategies in juvenile loggerhead turtles Caretta caretta of the North Pacific Ocean. Mar Ecol Prog Ser 425:269-280

Pilcher NJ, Chaloupka MY, Woods E (2012) Chelonia mydas (Hawaiian subpopulation). The IUCN Red List of Threatened Species 2012: e.T16285718A16285879

พ Pilcher NJ, Al-Maslamani I, Williams J, Gasang R, Chikhi A (2015) Population structure of marine turtles in coastal waters of Qatar. Endang Species Res 28:163-174

* Polovina JJ, Balazs GH, Howell EA, Parker DM, Seki MP, Dutton PH (2004) Forage and migration habitat of loggerhead (Caretta caretta) and olive ridley (Lepidochelys olivacea) sea turtles in the central North Pacific Ocean. Fish Oceanogr 13:36-51

* Polovina J, Uchida I, Balazs G, Howell EA, Parker D, Dutton P (2006) The Kuroshio Extension Bifurcation Region: a pelagic hotspot for juvenile loggerhead sea turtles. Deep Sea Res II 53:326-339

* Putman NF, Mansfield KL (2015) Direct evidence of swimming demonstrates active dispersal in the sea turtle 'lost years'. Curr Biol 25:1221-1227

* Putman NF, Mansfield KL, He R, Shaver DJ, Verley P (2013) Predicting the distribution of oceanic-stage Kemp's ridley sea turtles. Biol Lett 9:20130345

R Core Team (2016) R: a language and environment for statistical computing. R Foundation for Statistical Computing, Vienna

Ramirez MD, Avens L, Seminoff J, Goshe LR, Heppell S (2015) Patterns, duration, and timing of ontogenetic shifts in juvenile loggerhead sea turtles of the Northwest Atlantic Ocean. Ecosphere 6:art244

* Ramirez MD, Avens L, Seminoff JA, Goshe LR, Heppell SS (2017) Growth dynamics of juvenile loggerhead sea turtles undergoing an ontogenetic habitat shift. Oecologia 183:1087-1099

Kees AF, Alfaro-Shigueto J, Barata PCR, Bjorndal KA and others (2016) Are we working towards global research priorities for management and conservation of sea turtles? Endang Species Res 31:337-382

Kees AF, Avens L, Ballorain K, Bevan E and others (2018) The potential of unmanned aerial systems for sea turtle research and conservation: a review and future directions. Endang Species Res 35:81-100

* Richardson PB, Bruford MW, Calosso MC, Campbell LM and others (2009) Marine turtles in the Turks and Caicos Islands: remnant rookeries, regionally significant foraging stocks, and a major turtle fishery. Chelonian Conserv Biol 8:192-207

* Rincon-Diaz MP, Diez CE, van Dam RP, Sabat AM (2011) Effect of food availability on the abundance of juvenile 
hawksbill sea turtles (Eretmochelys imbricata) in inshore aggregation areas of the Culebra Archipelago, Puerto Rico. Chelonian Conserv Biol 10:213-221

Riskas KA, Fuentes MMPB, Hamann M (2016) Justifying the need for collaborative management of fisheries bycatch: a lesson from marine turtles in Australia. Biol Conserv 196:40-47

Riskas KA, Tobin RC, Fuentes MMPB, Hamann M (2018) Evaluating the threat of IUU fishing to sea turtles in the Indian Ocean and Southeast Asia using expert elicitation. Biol Conserv 217:232-239

Ryder CE, Conant TA, Schroeder BA (2006) Report of the Workshop on Marine Turtle Longline Post-Interaction Mortality. Tech Memo NMFS-F/OPR-29. U.S. Dep. Commerce, NOAA, Bethesda, MD

Saba VS (2013) Oceanic habits and habitats: Dermochelys coriacea. In: Wyneken J, Lohmann KJ, Musick JA (eds) The biology of sea turtles, Vol 3. CRC Press, Boca Raton, FL, p 163-188

Salmon M, Hamann M, Wyneken J, Schauble C (2009) Early swimming activity of hatchling flatback sea turtles Natator depressus: a test of the 'predation risk' hypothesis. Endang Species Res 9:41-47

Salmon M, Hamann M, Wyneken J (2010) The development of early diving behavior by juvenile flatback sea turtles (Natator depressus). Chelonian Conserv Biol 9: 8-17

Salmon M, Wyneken J, Hamann M, Whiting S (2016) Early growth and development of morphological defenses in post-hatchling flatbacks (Natator depressus) and green turtles (Chelonia mydas). Mar Freshw Behav Physiol 49: 421-435

Santos MN, Coelho R, Fernandez-Carvalho J, Amorim S (2012) Effects of hook and bait on sea turtle catches in an equatorial Atlantic pelagic longline fishery. Bull Mar Sci 88:683-701

Santos RG, Martins AS, Batista MB, Horta PA (2015) Regional and local factors determining green turtle Chelonia mydas foraging relationships with the environment. Mar Ecol Prog Ser 529:265-277

Sasso C, Epperly SP (2007) Survival of pelagic juvenile loggerhead turtles in the open ocean. J Wildl Manag 71: 1830-1835

Schmid JR, Barichivich WJ (2005) Developmental biology and ecology of the Kemp's ridley sea turtle. Lepidochelys kempii, in the eastern Gulf of Mexico. Chelonian Conserv Biol 4:828-834

Schmid JR, Witzell WN (2006) Seasonal migrations of immature Kemp's ridley turtle (Lepidochelys kempii Garman) along the west coast of Florida. Gulf Mex Sci 1:28-40

Schmid JR, Bolten AB, Bjorndal KA, Lindberg WJ, Percival HF, Zwick PD (2003) Home range and habitat use by Kemp's ridley turtles in west-central Florida. J Wildl Manag 67:196-206

Schuyler QA, Wilcox C, Townsend KA, WedemeyerStrombel KR, Balazs G, van Sebille E, Hardesty BD (2016) Risk analysis reveals global hotspots for marine debris ingestion by sea turtles. Glob Change Biol 22: 567-576

* Seminoff JA, Eguchi T, Carretta J, Allen CD and others (2014) Loggerhead sea turtle abundance at a foraging hotspot in the eastern Pacific Ocean: implications for atsea conservation. Endang Species Res 24:207-220

Seney EE, Landry AM Jr (2011) Movement patterns of immature and adult female Kemp's ridley sea turtles in the northwestern Gulf of Mexico. Mar Ecol Prog Ser 440: 241-254

* Senko J, Mancini A, Seminoff JA, Koch V (2014) Bycatch and directed harvest drive high green turtle mortality at Baja California Sur, Mexico. Biol Conserv 169:24-30

Shillinger GL, Bailey H, Bograd SJ, Hazen EL and others (2012) Tagging through the stages: technical and ecological challenges in observing life histories through biologging. Mar Ecol Prog Ser 457:165-170

Stacy BA, Keene JL, Schroeder BA (2016) Report of the Technical Expert Workshop: Developing National Criteria for Assessing Post-Interaction Mortality of Sea Turtles in Trawl, Net, and Pot/Trap Fisheries. Tech Memo NMFS-OPR-53. U.S. Department of Commerce, NOAA, Shepherdstown, WV

Stephenson RL, Paul S, Pastoors MA, Kraan M and others (2016) Integrating fishers' knowledge research in science and management. ICES J Mar Sci 73:1459-1465

Stewart K, Norton T, Mohammed H, Browne D and others (2016) Effects of 'swim with the turtles' tourist attractions on green sea turtle (Chelonia mydas) health in Barbados, West Indies. J Wildl Dis 52:S104-S117

Stokes LW, Epperly SP, McCarthy KJ (2012) Relationship between hook type and hooking location in sea turtles incidentally captured in the United States Atlantic pelagic longline fishery. Bull Mar Sci 88:703-718

* Strindberg S, Coleman RA, Burns Perez VR, Campbell CL, Majil I, Gibson J (2016) In-water assessments of sea turtles at Glover's Reef Atoll, Belize. Endang Species Res 31: 211-225

* Stringell TB, Calosso MC, Claydon JAB, Clerveaux W and others (2013) Marine turtle harvest in a mixed smallscale fishery: evidence for revised management measures. Ocean Coast Manag 82:34-42

* Sutherland WJ, Bailey MJ, Bainbridge IP, Brereton T and others (2008) Future novel threats and opportunities facing UK biodiversity identified by horizon scanning. J Appl Ecol 45:821-833

* Swimmer Y, Arauz R, McCracken M, McNaughton L and others (2006) Diving behavior and delayed mortality of olive ridley sea turtles Lepidochelys olivacea after their release from longline fishing gear. Mar Ecol Prog Ser 323:253-261

* Sykora-Bodie ST, Bezy V, Johnston DW, Newton E, Lohmann KJ (2017) Quantifying nearshore sea turtle densities: applications of unmanned aerial systems for population assessments. Sci Rep 7:17690

*Temple AJ, Kiszka JJ, Stead SM, Wambiji N and others (2018) Marine megafauna interactions with small-scale fisheries in the southwestern Indian Ocean: a review of status and challenges for research and management. Rev Fish Biol Fish 28:89-115

* Tikochinski Y, Bradshaw P, Mastrogiacomo A, Broderick A and others (2018) Mitochondrial DNA short tandem repeats unveil hidden population structuring and migration routes of an endangered marine turtle. Aquat Conserv 28:788-797

* Tiwari M, Wallace BP, Girondot M (2013) Dermochelys coriacea (West Pacific Ocean subpopulation). The IUCN Red List of Threatened Species 2013: e.T46967817 A46967821. http://www.iucnredlist.org/details/46967817/0

* Tomás J, Raga JA (2008) Occurrence of Kemp's ridley sea turtle (Lepidochelys kempii) in the Mediterranean. Mar Biodivers Rec 1:e58

* Turner-Tomaszewicz CN, Seminoff JA, Avens L, Goshe LR 
and others (2015) Age and residency duration of loggerhead turtles at a North Pacific bycatch hotspot using skeletochronology. Biol Conserv 186:134-142

* Turner-Tomaszewicz CN, Seminoff JA, Avens L, Goshe LR, Rguez-Baron JM, Peckham SH, Kurle CM (2018) Expanding the coastal forager paradigm: long-term pelagic habitat use by green turtles Chelonia mydas in the eastern Pacific Ocean. Mar Ecol Prog Ser 587:217-234

van Dam RP, Diez CE (1998) Home range of immature hawksbill turtles (Eretmochelys imbricata (Linnaeus)) at two Caribbean islands. J Exp Mar Biol Ecol 220:15-24

van Dam RP, Diez CE (1999) Differential tag retention in Caribbean hawksbill turtles. Chelonian Conserv Biol 3: 225-229

*Vander Zanden HB, Arthur KE, Bolten AB, Popp BN and others (2013a) Trophic ecology of a green turtle breeding population. Mar Ecol Prog Ser 476:237-249

Vander Zanden HB, Bjorndal KA, Bolten AB (2013b) Temporal consistency and individual specialization in resource use by green turtles in successive life stages. Oecologia 173:767-777

* Vélez-Rubio GM, Estrades A, Fallabrino A, Tomás J (2013) Marine turtle threats in Uruguayan waters: insights from 12 years of stranding data. Mar Biol 160:2797-2811

Vélez-Rubio GM, Teryda N, Asaroff PE, Estrades A, Rodriguez D, Tomás J (2018) Differential impact of marine debris ingestion during ontogenetic dietary shift of green turtles in Uruguayan waters. Mar Pollut Bull 127: 603-611

Velez-Zuazo X, Ramos WD, Van Dam RP, Diez CE, AbreuGrobois A, McMillan WO (2008) Dispersal, recruitment and migratory behaviour in a hawksbill sea turtle aggregation. Mol Ecol 17:839-853

Wallace BP, Crowder LB, Lewison RL, McDonald SL and others (2010a) Global patterns of marine turtle bycatch. Conserv Lett 3:131-142

Wallace BP, DiMatteo AD, Hurley BJ, Finkbeiner EM and others (2010b) Regional management units for marine turtles: a novel framework for prioritizing conservation and research across multiple scales. PLOS ONE 5:e15465

Wallace BP, DiMatteo AD, Bolten AB, Chaloupka MY and others (2011) Global Conservation priorities for marine turtles. PLOS ONE 6:e24510

Wallace BP, Kot CY, DiMatteo AD, Lee T, Crowder LB, Lewison RL (2013a) Impacts of fisheries bycatch on marine turtle populations worldwide: toward conservation and research priorities. Ecosphere 4:40

Wallace BP, Tiwari M, Girondot M (2013b) Dermochelys

Editorial responsibility: Rory Wilson,

Swansea, UK coriacea (East Pacific Ocean subpopulation). The IUCN Red List of Threatened Species 2013: e.T46967807 A46967809

Wallace BP, Stacy BA, Rissing M, Cacela D and others (2017) Estimating sea turtle exposures to Deepwater Horizon oil. Endang Species Res 33:51-67

*Weber SB, Weber N, Ellick J, Avery A and others (2014) Recovery of the South Atlantic's largest green turtle nesting population. Biodivers Conserv 23:3005-3018

*Wedding LM, Maxwell SM, Hyrenbach D, Dunn DC and others (2016) Geospatial approaches to support pelagic conservation planning and adaptive management. Endang Species Res 30:1-9

*Wildermann N, Critchell K, Fuentes M, Limpus CJ, Wolanski E, Hamann M (2017) Does behaviour affect the dispersal of flatback post-hatchlings in the Great Barrier Reef? R Soc Open Sci 4:170164

WWilliams JL, Pierce SJ, Rohner CA, Fuentes MMPB, Hamann M (2017) Spatial distribution and residency of green and loggerhead sea turtles using coastal reef habitats in southern Mozambique. Front Mar Sci 3:288

*Williard AS, Hall AG, Fujisaki I, McNeill JB (2017) Oceanic overwintering in juvenile green turtles Chelonia mydas from a temperate latitude foraging ground. Mar Ecol Prog Ser 564:235-240

Witherington B, Hirama S, Hardy R (2012) Young sea turtles of the pelagic Sargassum-dominated drift community: habitat use, population density, and threats. Mar Ecol Prog Ser 463:1-22

*Witt MJ, Penrose R, Godley BJ (2007) Spatio-temporal patterns of juvenile marine turtle occurrence in waters of the European continental shelf. Mar Biol 151:873-885

Witzell WN, Schmid JR (2005) Diet of immature Kemp's ridley turtles (Lepidochelys kempii) from Gullivan Bay, Ten Thousand Islands, southwest Florida. Bull Mar Sci 77: 191-200

Work TM, Balazs GH (2002) Necropsy findings in sea turtles taken as bycatch in the North Pacific longline fishery. Fish Bull 100:876-880

Wyneken J, Salmon M, Hamann M (2010) Swimming and early diving behavior by juvenile flatback sea turtles (Natator depressus). Integr Comp Biol 50:E193

Wyneken J, Lohmann KJ, Musick JA (eds) (2013) The biology of sea turtles, Vol 3. CRC Press, Boca Raton, FL

Zug GR, Balazs GH, Wetherall JA, Parker DM, Murakawa SK (2002) Age and growth of Hawaiian seaturtles (Chelonia mydas): an analysis based on skeletochronology. Fish Bull 100:117-127

Submitted: May 8, 2018; Accepted: July 23, 2018

Proofs received from author(s): September 2, 2018 